\title{
Measurements of volatile organic compounds at a suburban ground site (T1) in Mexico City during the MILAGRO 2006 campaign: measurement comparison, emission ratios, and source attribution
}

\author{
D. M. Bon ${ }^{1,2,3}$, I. M.Ulbrich ${ }^{2,3}$, J. A. de Gouw ${ }^{1,2}$, C. Warneke $^{1,2}$, W. C. Kuster ${ }^{1}$, M. L. Alexander ${ }^{4}$, A. Baker ${ }^{5}$, \\ A. J. Beyersdorf ${ }^{5,}$, D. Blake ${ }^{5}$, R. Fall ${ }^{2,3}$, J. L. Jimenez ${ }^{2,3}$, S. C. Herndon ${ }^{6}$, L. G. Huey ${ }^{7}$, W. B. Knighton ${ }^{8}$, J. Ortega ${ }^{4, * *}$, \\ S. Springston ${ }^{9}$, and $\mathrm{O}$. Vargas ${ }^{7}$ \\ ${ }^{1}$ NOAA Earth System Research Laboratory, Boulder, Colorado, USA \\ ${ }^{2}$ Cooperative Institute for Research in Environmental Sciences, University of Colorado, Boulder, Colorado, USA \\ ${ }^{3}$ Department of Chemistry and Biochemistry, University of Colorado, Boulder, Colorado, USA \\ ${ }^{4}$ Pacific Northwest National Laboratory, Richland, Washington, USA \\ ${ }^{5}$ University of California, Irvine, California, USA \\ ${ }^{6}$ Aerodyne Research Inc. Billerca, Massachusetts, USA \\ ${ }^{7}$ Georgia Institute of Technology, Atlanta, Georgia, USA \\ ${ }^{8}$ Montana State University, Bozeman, Montana, USA \\ ${ }^{9}$ Brookhaven National Laboratory, Upton, New York, USA \\ *now at: NASA Langley Research Center, Hampton, Virginia, USA \\ ** now at: National Center for Atmospheric Research, Atmospheric Chemistry Division, Boulder, Colorado, USA
}

Received: 15 September 2010 - Published in Atmos. Chem. Phys. Discuss.: 8 October 2010

Revised: 28 February 2011 - Accepted: 8 March 2011 - Published: 16 March 2011

\begin{abstract}
Volatile organic compound (VOC) mixing ratios were measured with two different instruments at the T1 ground site in Mexico City during the Megacity Initiative: Local and Global Research Observations (MILAGRO) campaign in March of 2006. A gas chromatograph with flame ionization detector (GC-FID) quantified 18 light alkanes, alkenes and acetylene while a proton-transfer-reaction iontrap mass spectrometer (PIT-MS) quantified 12 VOC species including oxygenated VOCs (OVOCs) and aromatics. A GC separation system was used in conjunction with the PIT-MS (GC-PIT-MS) to evaluate PIT-MS measurements and to aid in the identification of unknown VOCs. The VOC measurements are also compared to simultaneous canister samples and to two independent proton-transfer-reaction mass spectrometers (PTR-MS) deployed on a mobile and an airborne platform during MILAGRO. VOC diurnal cycles demonstrate the large influence of vehicle traffic and liquid propane gas (LPG) emissions during the night and photochemical processing during the afternoon. Emission ratios for VOCs and OVOCs relative to $\mathrm{CO}$ are derived from early-morning
\end{abstract}

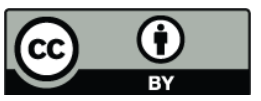

Correspondence to: J. A. de Gouw (joost.degouw@noaa.gov) measurements. Average emission ratios for non-oxygenated species relative to $\mathrm{CO}$ are on average a factor of $\sim 2$ higher than measured for US cities. Emission ratios for OVOCs are estimated and compared to literature values the northeastern US and to tunnel studies in California. Positive matrix factorization analysis (PMF) is used to provide insight into VOC sources and processing. Three PMF factors were distinguished by the analysis including the emissions from vehicles, the use of liquid propane gas and the production of secondary VOCs + long-lived species. Emission ratios to CO calculated from the results of PMF analysis are compared to emission ratios calculated directly from measurements. The total PIT-MS signal is summed to estimate the fraction of identified versus unidentified VOC species.

\section{Introduction}

Recent estimates of the global emission of volatile organic compounds (VOCs) into the atmosphere range from about 1200 to $1600 \mathrm{TgC} \mathrm{yr}^{-1}$ (Olivier et al., 2005; Goldstein and Galbally, 2007; Reimann and Lewis, 2007; Williams and Koppmann, 2007; Yokelson et al., 2008). Major sources of atmospheric VOCs include vegetative emission, biomass

Published by Copernicus Publications on behalf of the European Geosciences Union. 
burning, and the use of fossil fuels. On a global scale, VOC emissions are dominated by isoprene, which accounts for about $65 \%$ of biogenic emissions and $40 \%$ of total VOC emissions (Guenther et al., 1995, 2006; Williams and Koppmann, 2007). Biomass burning, both natural and as the result of human activity, and fossil fuel use are each thought to account for about $10 \%$ of global VOC emissions (Reimann and Lewis, 2007). Recent estimates suggest the contribution from biomass burning could be as large as $500 \mathrm{TgC}_{\mathrm{yr}}{ }^{-1}$ (Yokelson et al., 2008). Regardless of global emissions, any of these sources can dominate locally and regionally. Anthropogenic VOC emissions often dominate in areas of high population density and contribute significantly to urban air pollution (Olivier et al., 2005; Reimann and Lewis, 2007). Air pollution is of growing international concern and contributes to approximately 2 million premature deaths per year worldwide (World Health Organization, 2008).

In and around heavily populated urban areas, VOCs released as a result of fossil fuel use are significant contributors to the formation of photochemical smog and groundlevel ozone. Ozone, a secondary pollutant that is formed by photochemical reactions involving VOCs and nitrogen oxides $\left(\mathrm{NO}_{\mathrm{x}}\right)$, has direct adverse effects on human health and can damage agricultural crops (Finlayson-Pitts, 1997; Krupa et al., 2001). Urban VOCs can also contribute to formation of particulate pollution that has significant detrimental effects on human health (Brunekreef and Forsberg, 2005; van Zelm et al., 2008). VOCs and particulate emissions related to human activity and the subsequent formation of secondary organic aerosol (SOA) have the potential to affect climate (Ramanathan et al., 2007). Mechanisms of SOA formation from urban VOCs are not well understood (de Gouw et al., 2005; Volkamer et al., 2006; Hallquist et al., 2009).

The Mexico City Metropolitan Area (MCMA), a highaltitude sub-tropical megacity with a population of about 18 million people, is an urban center where a dense population and a local geography that restricts transport, contribute to the city's significant air quality problems. Hydrocarbon measurements in 1993, 2002, and 2003 showed highly elevated levels of many anthropogenic VOCs within the city (Blake and Rowland, 1995; Rogers et al., 2006; Velasco et al., 2007). The MILAGRO campaign (Megacity Initiative: Local and Global Research Observations) in March 2006 was designed to address the impact of these emissions on a variety of scales from local to global, and builds on results from smaller multi-investigator campaigns such as IMADAAVER and MCMA-2003 (Edgerton et al., 1999; Molina et al., 2007, 2010).

During MILAGRO a variety of different instruments and techniques were used to quantify VOCs from both fixed sites and mobile platforms (Heald et al., 2008; Apel et al., 2010). VOC measurements were made by two different groundbased instruments at the sub-urban T1 site (Fast et al., 2007): an in-situ gas chromatograph with flame ionization detection (GC-FID) was used to measure light hydrocarbons and a proton-transfer-reaction ion-trap mass spectrometer (PITMS) was used to measure acetonitrile, aromatics and oxygenated VOCs (de Gouw et al., 2009). Here, these measurements are compared with canister sample analyses and with proton-transfer-reaction mass spectrometry (PTR-MS) measurements made from the Aerodyne mobile laboratory and from the US Department of Energy G1 aircraft. Because the Aerodyne mobile laboratory and the G1 aircraft also sampled near other surface sites and because canister samples were collected at many surface sites and from the NASA DC-8 and NCAR C-130 aircraft, these comparisons can be used to evaluate the consistency of VOC data obtained throughout the campaign (Kleinman et al., 2008; Fortner et al., 2009; Karl et al., 2009; Apel et al., 2010). In addition, this study supplements our understanding of the specificity of proton-transfer-reaction mass spectrometry (PTR-MS) measurements in a dense megacity with a complex VOC composition that challenges the analytical capabilities of this technique (de Gouw and Warneke, 2007).

Diurnal cycles of most VOCs at T1 were pronounced with a high peak in the morning when emissions accumulated in a shallow mixing layer (de Gouw et al., 2009). A similar diurnal pattern was observed during the MCMA-2003 study and at the T0 ground site during the MILAGRO campaign (Velasco et al., 2007; Fortner et al., 2009). The T1 data are used here to determine urban emission ratios versus $\mathrm{CO}$, and these are compared to those from previous studies in the US (Warneke et al., 2007; Baker et al., 2008; Ban-Weiss et al., 2008). The effects of chemical removal and production of VOCs were pronounced in the afternoon and are discussed elsewhere in more detail (de Gouw et al., 2009).

Positive Matrix Factorization (PMF), a factorization model widely used for environmental source apportionment (Paatero and Tapper, 1994; Ulbrich et al., 2009) is applied here to the VOC data collected at T1 during the campaign. PMF and other similar factorization methods (e.g. Principal Component Analysis) have been applied previously for VOC measurements at urban ground sites where VOCs have distinct sources or diurnal profiles (Harley et al., 1992; Buzcu and Fraser, 2006; Millet et al., 2006; Legreid et al., 2007; Song et al., 2007). We use the results from the PMF analysis to estimate emission ratios and compare these with emission ratios derived directly from ground-based VOC measurements.

\section{Methods}

\subsection{VOC measurements at T1}

The $\mathrm{T} 1$ ground site $\left(19^{\circ} 42^{\prime} 11^{\prime \prime} \mathrm{N}, 98^{\circ} 58^{\prime} 55^{\prime \prime} \mathrm{W}\right)$ was located $30 \mathrm{~km}$ to the northeast of Mexico City on the campus of the Universidad Tecnológica de Tecámac (UTTEC). VOC measurements at the site were made using (1) a custombuilt proton-transfer ion-trap mass spectrometer (PIT-MS), 


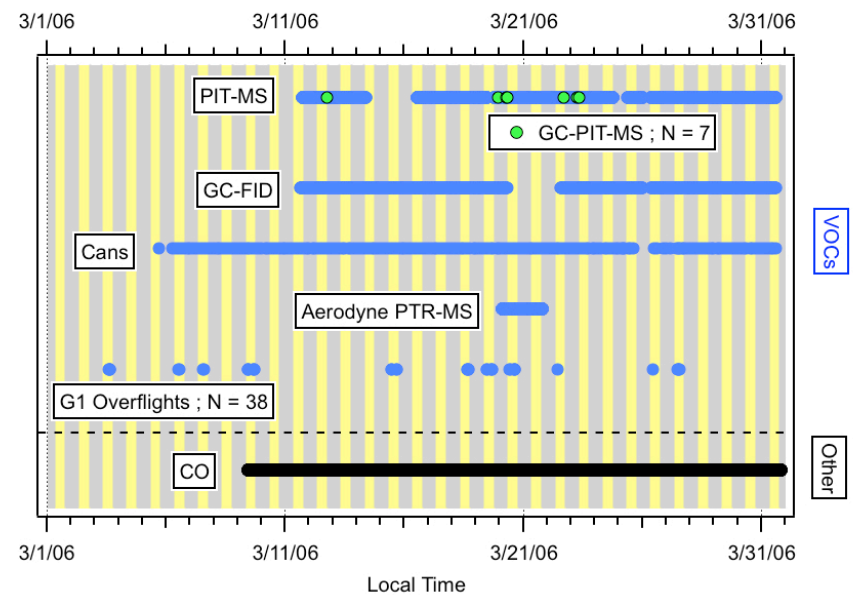

Fig. 1. Sampling periods for the VOC measurement methods and $\mathrm{CO}$ at the $\mathrm{T} 1$ ground site in Mexico City during the MILAGRO campaign. Approximate daylight hours (07:00-19:00 local time) are shown in yellow.

and (2) a gas chromatograph with flame ionization detection (GC-FID). These measurements will be compared here with the results of VOC measurements of canister samples collected at the site, and from two mobile platforms at or above T1. A PTR-MS instrument measured VOCs from the Aerodyne mobile laboratory while it was located at the site on 20-21 March. Another PTR-MS instrument measured VOCs from the DOE G-1 aircraft during multiple over flights of T1. Figure 1 gives an overview of when the different VOC measurements at T1 were made. Sampling frequency, averaging periods and limits of detection are summarized in Table 1. A complete list of species quantified can be found in Table 2 .

\subsection{Instrumentation}

\subsubsection{NOAA GC-FID}

Five-minute integrated samples of light hydrocarbons were collected cryogenically every $15 \mathrm{~min}$ and injected into a gas chromatograph equipped with a $50 \mathrm{~m}$ DB-5 alumina column divided in half to allow back flushing, which shortens analysis time. A flame ionization detector was used to quantify 18 VOCs in the C2-C6 range with a detection limit of $\sim 5$ pptv. Calibrations were made 1-2 times per day from a gas standard. A detailed description of this instrument is given elsewhere (Goldan et al., 2000). Samples were collected from an air intake approximately $6 \mathrm{~m}$ above ground level that was shared with the PIT-MS system described below. Both instruments sampled outside air pumped through $1 / 4$ " PFA Teflon tubing at a rate of 3 SLM. The precision of the measurements is estimated to be $5 \%$ from the reproducibility of calibration measurements made from one calibration mixture during the campaign. The accuracy is estimated to be $10 \%$ based on the variability between different calibration mixtures.

\subsubsection{NOAA PIT-MS}

The PIT-MS instrument uses an ion source and drift-tube reactor similar to that of a commercial PTR-MS instrument, but is equipped with an ion trap mass spectrometer instead of a quadrupole mass filter (Warneke et al., 2005a, b). During MILAGRO, the PIT-MS provided simultaneous measurements of product ions with mass to charge ratios $(\mathrm{m} / \mathrm{z})$ from 33 to $225 \mathrm{amu}$ at a frequency of $5 \mathrm{~min}^{-1}$. Calibrations using a gas standard were performed automatically every $2 \mathrm{~h}$ and manually using multiple dilution steps approximately once per week. Twelve different VOCs and OVOCs were quantified based on previous identification in the literature (de Gouw and Warneke, 2007). Final PIT-MS data were reported as 5minute averages for easy comparison with the GC-FID data and to improve signal-to-noise.

The measurement precision is calculated using ioncounting statistics as detailed elsewhere (Hayward et al., 2002; de Gouw et al., 2003; de Gouw and Warneke, 2007). Towards the end of the MILAGRO campaign, degradation of the PIT-MS secondary electron multiplier (SEM) detector resulted in increased noise and higher limits of detection for this period (Table 1). Accuracies for most species quantified by PIT-MS are estimated at $20 \%$. NOAA PIT-MS mixing ratios for $\mathrm{C} 8$ and $\mathrm{C} 9$ aromatics were calculated using p-xylene and 1,2,4-trimethyl benzene in a calibration standard. The quantification of acetic acid, formic acid, naphthlane, and the higher ( $>\mathrm{C} 7)$ aromatics is less accurate $(50 \%)$ due to the lack of adequate calibration standards for these compounds. Benzene was detected by PIT-MS during MILAGRO but suffered from interference from clusters of water with protonated acetic acid and was not reported in final data for the campaign.

In order to distinguish isomers and identify unknown compounds detected by PIT-MS, a GC pre-separation method (GC-PIT-MS) was used on seven occasions predominantly at times when morning maxima in VOC mixing ratios occurred. In GC-PIT-MS mode, the PIT-MS instrument is coupled to a gas chromatograph fitted with a temperature programmed DB-624 column (Warneke et al., 2003). Air samples are collected in a liquid-nitrogen cooled cryogenic trap prior to injection onto the GC column. GC-PIT-MS produces a chromatogram for each of the about 180 product ion masses monitored by PIT-MS. While measuring the column effluent, the PIT-MS was operated with a time resolution of $2 \mathrm{~s}$. Typical VOC peak width was $4 \mathrm{~s}$ or less and therefore peaks were under-sampled and cannot be used for quantification.

\subsubsection{UCI canisters}

Whole air samples were collected by the University of California, Irvine in $2 \mathrm{~L}$ electro-polished, pre-treated, evacuated stainless steel sampling canisters. Each canister was filled for $3 \mathrm{~h}$ and was pressurized to about $100 \mathrm{kPa}$. After sample collection, the canisters were returned to the University of 
Table 1. Limits of detection for individual VOCs quantified during the MILAGRO campaign by PIT-MS and PTR-MS.

\begin{tabular}{|c|c|c|c|c|}
\hline \multirow{2}{*}{$\begin{array}{r}\text { Instrument: } \\
\text { period: } \\
\text { date: }\end{array}$} & \multicolumn{2}{|c|}{$\begin{array}{l}\text { NOAA PIT-MS } \\
5 \mathrm{~min}\end{array}$} & \multirow[t]{2}{*}{$\begin{array}{c}\text { Aerodyne PTR-MS } \\
1 \sigma\end{array}$} & \multirow[t]{2}{*}{$\begin{array}{c}\text { DOE PTR-MS } \\
1 \sigma\end{array}$} \\
\hline & 11-27 Mar & 28-31 Mar* & & \\
\hline Compound & \multicolumn{2}{|c|}{ Limit of Detection (pptv) } & & \\
\hline toluene & 150 & $(800)$ & 110 & 100 \\
\hline$\Sigma \mathrm{C} 8$ aromatics & 100 & $(800)$ & 200 & 110 \\
\hline$\Sigma \mathrm{C} 9$ aromatics & 100 & $(800)$ & 160 & 110 \\
\hline$\Sigma \mathrm{C} 10$ aromatics & 100 & $(800)$ & & \\
\hline$\Sigma \mathrm{C} 11$ aromatics & 100 & $(800)$ & & \\
\hline naphthalene & 100 & $(800)$ & & \\
\hline methanol & 1500 & $(1500)$ & 530 & \\
\hline acetaldehyde & 300 & $(1500)$ & 400 & 350 \\
\hline acetone & 150 & $(800)$ & 230 & 250 \\
\hline acetic acid & 300 & (1200) & 350 & \\
\hline methyl ethyl ketone & 300 & $(2000)$ & 150 & \\
\hline acetonitrile & 100 & $(800)$ & & 85 \\
\hline
\end{tabular}

* PIT-MS LODs reported for two periods 11-27 March and 28-31 March . LOD changed due to hardware problems.

California, Irvine, where they were analyzed for $\mathrm{CH}_{4}, \mathrm{CO}$, hydrocarbons, halocarbons and alkyl nitrates. Detection limits for all species compared here were less than 3 pptv with precisions between $1 \%$ and $4 \%$. For more detailed descriptions of the UCI measurements we refer to (Colman et al., 2001). Canister samples were also collected at the T0 ground site and onboard the NASA DC-8 and NCAR C-130 aircraft, and analyzed using the same methodology.

\subsubsection{Aerodyne PTR-MS}

A commercial PTR-MS (Ionicon Analytik, Austria) instrument was deployed on the Aerodyne mobile laboratory during the campaign (Rogers et al., 2006; Herndon et al., 2008). The mobile laboratory was parked at the $\mathrm{T} 1$ site for approximately $40 \mathrm{~h}$ from 04:00 UTC on 20 March 2006 until 18:00 UTC on 21 March 2006. Calibrations were made at regular intervals using a gas calibration standard and average calibration factors were applied to the data after the campaign. Two scan modes were used for the mobile laboratory PTR-MS. In the first mode, 24 scans of 9 masses were made each with a one second dwell time. This was followed by 12 cycles of the full mass range (20-160 amu) with a $0.1 \mathrm{~s}$ dwell time. The data obtained in both modes were averaged on a 1-min time basis for comparison to PIT-MS measurements during this period.

\subsubsection{DOE PTR-MS}

The Pacific Northwest National Laboratory deployed a commercial PTR-MS on the DOE G1 aircraft. Eleven VOCs were measured with a frequency of $0.1 \mathrm{~s}^{-1}$. PTR-MS dwell times on the aircraft ranged from $0.5-1.0 \mathrm{~s}$ per mass and calibrations were typically done at least twice per flight day. Thirty-eight over-flights of T1 occurred during MILAGRO.

\subsubsection{Carbon monoxide measurements}

Carbon monoxide measurements were made at the $\mathrm{T} 1$ ground site by the Georgia Institute of Technology using a modified Thermo Electron 48C CO monitor (Parrish et al., 1994). $\mathrm{CO}$ measurements were reported on a 1-minute time base. The precision and accuracy of these data are estimated to be \pm 5 ppbv and $\pm 5 \%$, respectively.

CO was also quantified by gas chromatography from the UC Irvine canisters. These measurements agreed with the insitu measurements averaged over the canister sampling periods to within $5 \%\left(r^{2}=0.90\right)$.

\subsection{Positive Matrix Factorization (PMF)}

\subsubsection{PMF method}

The PMF algorithm solves the bilinear, receptor-only, unmixing model, with positively-constrained factor values, and has been widely used for factor analysis and sourceapportionment of both particulate matter and VOC measurements (Zhao et al., 2004; Brown et al., 2007; Engel-Cox and Weber, 2007; Reff et al., 2007; Lanz et al., 2008; Ulbrich et al., 2009; Slowik et al., 2010). Some concepts that are relevant to the understanding of this work are briefly described here. For additional details about the method, the reader is referred to the above references.

For PMF analysis, data are assembled into a 2 dimensional $m \times n$ matrix $\mathbf{X}$ such that each of the $i$ rows contains the 
Table 2. Slopes resulting from ODR regression of scatter plots between VOCs measured by 2 or more techniques during MILAGRO. Also shown here are $1 \sigma$ uncertainties in slopes, correlation $\left(r^{2}\right)$ coefficients, and the number of points compared $(N)$.

\begin{tabular}{|c|c|c|c|}
\hline & best fit slope & $r^{2}$ & $N$ \\
\hline & $\begin{array}{l}\text { NOAA GC-FID: } \\
\text { UCI canisters }\end{array}$ & & \\
\hline propane & $0.98 \pm 0.04$ & 0.96 & 128 \\
\hline n-butane & $1.02 \pm 0.03$ & 0.97 & 128 \\
\hline i-butane & $1.02 \pm 0.03$ & 0.97 & 128 \\
\hline n-pentane & $1.04 \pm 0.03$ & 0.98 & 128 \\
\hline i-pentane & $0.89 \pm 0.02$ & 0.98 & 128 \\
\hline n-hexane & $0.94 \pm 0.03$ & 0.97 & 128 \\
\hline ethylene & $0.90 \pm 0.03$ & 0.97 & 129 \\
\hline propylene & $1.00 \pm 0.03$ & 0.97 & 128 \\
\hline 1-butene +2 -methyl propene & $0.99 \pm 0.04$ & 0.96 & 128 \\
\hline cis-2-butene & $0.95 \pm 0.04$ & 0.95 & 128 \\
\hline trans-2-butene & $0.79 \pm 0.03$ & 0.96 & 128 \\
\hline 1-pentene & $1.18 \pm 0.16$ & 0.87 & 71 \\
\hline cis-2-pentene & $1.00 \pm 0.06$ & 0.94 & 77 \\
\hline trans-2-pentene & $1.03 \pm 0.04$ & 0.96 & 98 \\
\hline 2-methy 2-butene & $0.78 \pm 0.07$ & 0.90 & 60 \\
\hline 3-methy 1-butene & $0.93 \pm 0.12$ & 0.87 & 82 \\
\hline \multirow[t]{2}{*}{ acetylene } & $0.74 \pm 0.04$ & 0.94 & 129 \\
\hline & $\begin{array}{l}\text { NOAA PIT-MS: } \\
\text { UCI canisters }\end{array}$ & & \\
\hline toluene & $1.07 \pm 1.74$ & 0.87 & 112 \\
\hline$\Sigma \mathrm{C} 8$ aromatics & $3.38 \pm 0.14$ & 0.87 & 108 \\
\hline \multirow[t]{2}{*}{$\Sigma \mathrm{C} 9$ aromatics } & $2.68 \pm 0.44$ & 0.72 & 101 \\
\hline & $\begin{array}{l}\text { NOAA PIT-MS: } \\
\text { Aerodyne PTR-MS }\end{array}$ & & \\
\hline methanol & $0.68 \pm 0.11$ & 0.84 & 1605 \\
\hline acetaldehyde & $1.10 \pm 0.21$ & 0.81 & 1695 \\
\hline acetone & $1.00 \pm 0.14$ & 0.86 & 1695 \\
\hline toluene & $1.61 \pm 0.18$ & 0.89 & 1685 \\
\hline$\Sigma \mathrm{C} 8$ aromatics & $1.39 \pm 0.18$ & 0.87 & 1685 \\
\hline \multirow[t]{2}{*}{$\Sigma \mathrm{C} 9$ aromatics } & $1.38 \pm 0.22$ & 0.84 & 1685 \\
\hline & $\begin{array}{l}\text { NOAA PIT-MS: } \\
\text { DOE G1 PTR-MS }\end{array}$ & & \\
\hline acetonitrile & $0.93 \pm 0.17$ & 0.06 & 15 \\
\hline acetaldehyde & $0.97 \pm 0.13$ & 0.18 & 15 \\
\hline acetone & $0.86 \pm 0.07$ & 0.50 & 15 \\
\hline acetic acid & $0.50 \pm 0.08$ & 0.10 & 15 \\
\hline methyl ethyl ketone & $0.84 \pm 0.09$ & 0.36 & 15 \\
\hline toluene & $1.07 \pm 0.14$ & 0.51 & 15 \\
\hline$\Sigma \mathrm{C} 8$ aromatics & $0.88 \pm 0.17$ & 0.04 & 15 \\
\hline$\Sigma \mathrm{C} 9$ aromatics & $0.30 \pm 0.14$ & 0.23 & 9 \\
\hline
\end{tabular}

measured VOC mixing ratios at sampling time $t_{i}$ and each of the $j$ columns contains the time series of a sampled $\mathrm{VOC}_{j}$. A corresponding matrix is assembled specifying the measurement precision ("uncertainty") for each point in the data matrix $\left(\sigma_{i j}\right)$. The bilinear unmixing model represents the mea- sured VOC concentrations as the sum of the contributions of $p$ factors, each of which is comprised of a chemical profile $(f)$ and a factor time series $(g)$, such that for each point in the data matrix $\left(\mathbf{X}_{i j}\right)$ :

$\mathbf{X}_{i j}=\sum_{p} g_{i p} f_{p j}+e_{i j}$

where $e_{i j}$ is the fit residual for each matrix (Paatero and Tapper, 1994; Paatero, 1997; Ulbrich et al., 2009).

The PMF algorithm finds solutions of the model by minimizing a "quality of fit" parameter $Q$ defined as:

$Q=\sum_{i=1}^{m} \sum_{j=1}^{n}\left(e_{i j} / \sigma_{i j}\right)^{2}$.

The minimum expected value of $Q /\left(Q_{\exp }\right)$ is obtained when all data elements have been fit within their uncertainty (i.e., $e_{i j} / \sigma_{i j} \sim 1$ ), thus $Q_{\exp }$ should be approximately $m \times n$ for large datasets. $Q$ values can be normalized to $Q_{\text {exp }}$, such that the expected best fit would have $Q / Q_{\exp } \sim 1$. The number of factors that best represent the dataset is ultimately chosen by the user, commonly based on both (1) quantities such as $Q / Q_{\text {exp }}$ that characterize the quality of the reconstruction, and (2) the physical plausibility of the factors. PMF solutions for a given number of factors are not mathematically unique, i.e. linear transformations ("rotations") of the factor time series and source profiles may result in a acceptable fit to the data with similar but slight larger values of $Q$ (Paatero and Hopke, 2009). A subset of approximate linear transformations can be explored in PMF using the FPEAK parameter.

In this study, we use the PMF2 algorithm in robust mode with default convergence and outlier criteria values. We evaluate the analysis using the recently-developed PMF Evaluation Tool (PET) (Ulbrich et al., 2009).

\subsubsection{Data preparation}

PIT-MS measurements were averaged over GC-FID sampling periods (Fig. 1, Table 1) for the period from 1127 March 2006. Periods when either instrument was off line were excluded from the PMF analysis. The data matrix for the analysis presented here consisted of 851 simultaneous measurements (rows) from the GC-FID and PIT-MS instruments, arranged so that 18 columns contain the time series of 18 species from the GC-FID, 12 columns contain the time series of 12 VOCs quantified by PIT-MS, and the final 35 columns contain the time series of 35 PIT-MS ion signals not quantified ( 65 columns total). The 35 PIT-MS ion signals chosen were not identified as specific molecules, but all did show a significant signal during the campaign.

For the GC-FID data we used 5 pptv or $5 \%$, whichever number was larger, to calculate errors for PMF analysis. Errors for the PIT-MS data were calculated using ion counting statistics (de Gouw and Warneke, 2007). The error for 11 PIT-MS masses with signal to noise ratios (SNR) less than 
2 was increased by a factor of 4 , as is typical for the PMF method (Paatero and Hopke, 2003; Ulbrich et al., 2009). None of the measurements considered in the analysis had a SNR $<1$. Error was increased for only one quantified PITMS mass $(\mathrm{m} / \mathrm{z}, 129$, naphthalene). Results of PMF analysis and an estimate of the uncertainties involved in this analysis are discussed in Sect. 4.

\section{Data quality evaluation}

The quality of VOC data obtained at T1 was evaluated using direct measurement comparisons between the two NOAA measurements and other measurements where possible. The selectivity of the PIT-MS data was evaluated using GC-PITMS analyses.

\subsection{Measurement comparisons}

\subsubsection{NOAA GC-FID versus UCI canisters}

The on-line GC-FID measurements were compared to UCI canister measurements for 17 compounds. For the purpose of these comparisons, the on-line GC-FID data were averaged over the 3-hour sampling times of the UCI canisters. Examples are shown for propane, ethylene and acetylene (Fig. 2ac). The data in Fig. 2 were fit using 2-sided, orthogonal distance regressions (ODR). The resulting regression slopes $(s)$, and values of the linear correlation coefficient $\left(r^{2}\right)$ are summarized in Table 2 for all 17 overlapping VOC measurements. For all VOCs, the degree of correlation between the in-situ and canister measurements was high $\left(r^{2}>0.87\right)$ and most measurements agreed within the $10 \%$ accuracy of the in-situ measurements. Notably, the canister measurements of acetylene (Fig. 2c) were systematically higher than those made in-situ. The reasons for this difference are unknown; calibration standards were not compared for the purpose of this study. Our GC measurements in the Arctic in 2008 were systematically higher than canister samples analyzed by the NOAA Global Monitoring Division (Gilman, et al., 2010). As reported in previous work (Apel et al., 1994), it appears that the accuracy of the measurement of acetylene is considerably outside the $10 \%$ calibration uncertainty estimated for other species. Further work is needed to resolve the considerable calibration discrepancies for this important species.

\subsubsection{NOAA PIT-MS versus UCI canisters}

Both the PIT-MS and the UCI canisters reported mixing ratios for aromatic compounds. An example of the comparisons is shown for toluene in Fig. 2d. The PIT-MS data were averaged onto the canister sampling times for the purpose of this plot. The two measurements correlated well and agreed quantitatively within 7\%. The other PIT-MS measurements of aromatics correlated well but were systematically higher than the UCI canister measurements (Table 2). The reasons for these differences are unknown; calibration standards were not compared for the purpose of this study.

PTR-MS measurements of higher aromatics represent the sums of many different isomers, each with its own calibration uncertainty. As a result, inter-comparisons tend to show larger differences than for single compounds (de Gouw and Warneke, 2007). For example, out of 5 published comparisons of $\mathrm{C} 8$ aromatic measurements, three studies compared within $20 \%$ and two showed differences of factors of 2 and 3. The GC-PIT-MS results presented later in this section show no significant interferences on masses associated with aromatic compounds that might explain these discrepancies. Previous work in the US also shows no evidence of interference on these masses (Warneke et al., 2003). We conclude that calibration uncertainties appear to be the most likely explanation for measurement disagreements.

\subsubsection{NOAA PIT-MS vs. Aerodyne PTR-MS}

The Aerodyne mobile laboratory collected data at the T1 site for two days during the campaign (Fig. 1). Six VOCs were measured by both the NOAA PIT-MS and the Aerodyne mobile laboratory PTR-MS. Figure 2e shows the measurement comparison for acetaldehyde. Slopes and correlation coefficients for all 6 VOC comparisons are summarized in Table 2. Correlation coefficients $\left(r^{2}\right)$ for all 6 compared compounds were greater than 0.80 .

The calibration standards used by both instruments were compared in the field during MILAGRO. PIT-MS measurements of methanol were systematically $32 \%$ lower than those of the Aerodyne PTR-MS. This difference is similar to the difference observed (35\%) between the calibration standards used with each of the two instruments. The PIT-MS measurements of reported aromatics were systematically $40-60 \%$ higher than the Aerodyne PTR-MS measurements (Table 2) but are within the combined measurement uncertainties. Unlike methanol, differences in calibration standards did not explain differences between measurements of aromatics.

\subsubsection{NOAA PIT-MS vs. DOE PTR-MS}

The DOE G1 aircraft flew over the $\mathrm{T} 1$ ground site 38 times during MILAGRO. All overpasses occurred in mid-afternoon when VOC mixing ratios for primary species were at or near daily minima. Aircraft overpass altitudes ranged between $800-2800 \mathrm{~m}$ above ground level with typical wellmixed daytime boundary layer depths of at least $2000 \mathrm{~m}$. Measurements of boundary layer heights indicate that overpasses of T1 occurred within the boundary layer (Shaw et al., 2007; Fast et al., 2009).

Eight VOC measurements were compared for the 15 overpasses when both instruments were operating. Overpasses were defined as measurements made by the DOE-G1 instrument within a horizontal distance of $5 \mathrm{~km}$ from the ground site. DOE-G1 PTR-MS measurements for each VOC during 


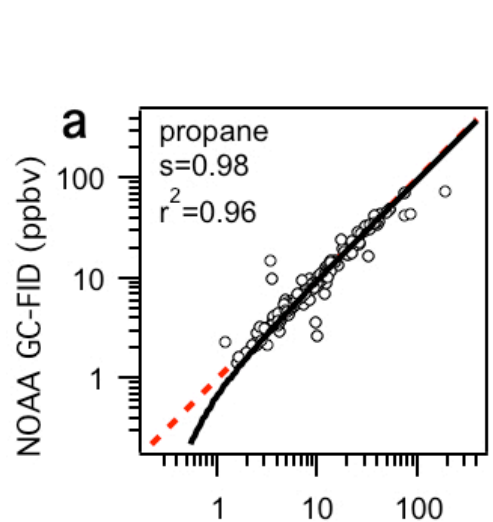

- best fit $\quad=-\cdot 1: 1$ line
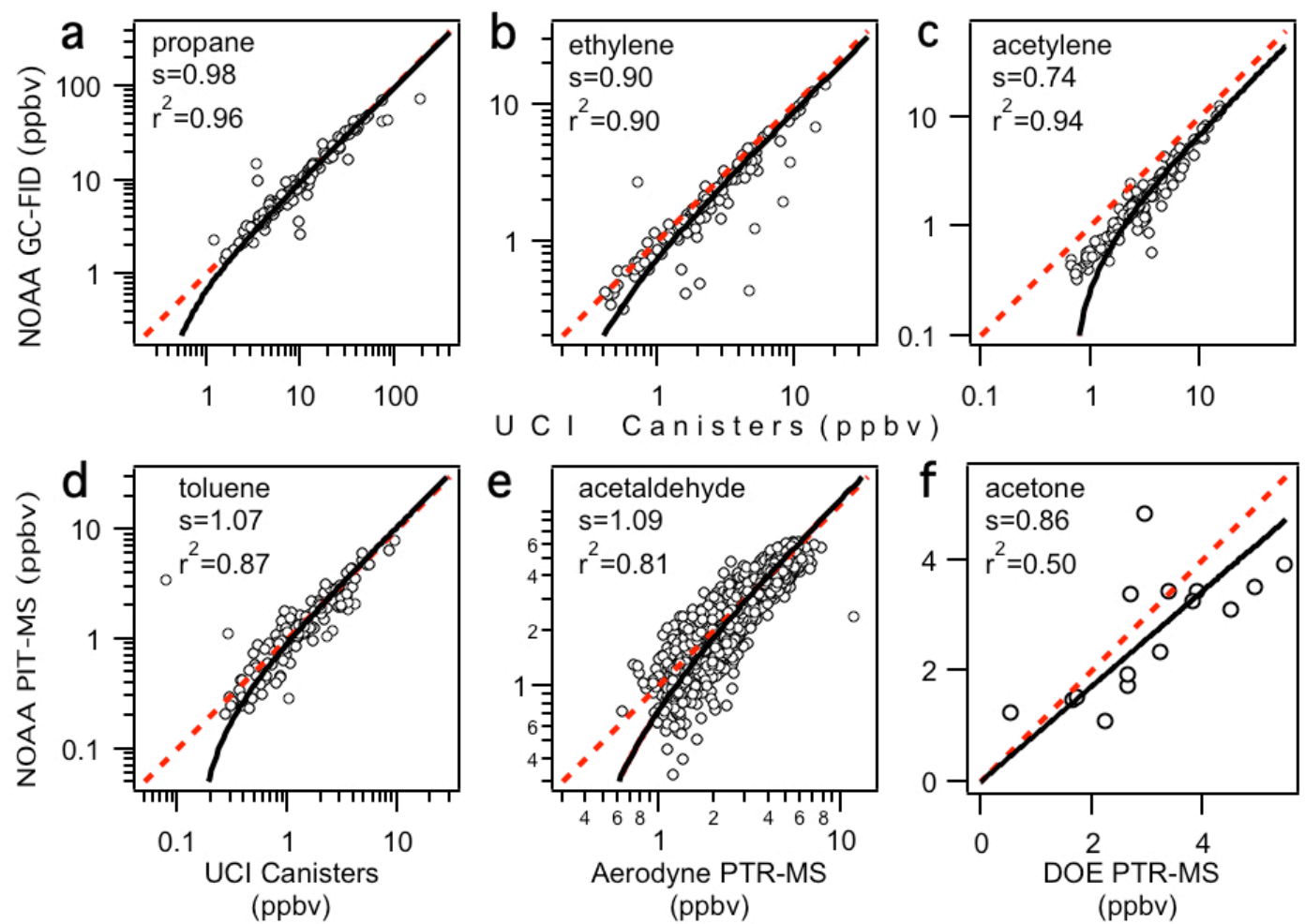

\section{U C I Canisters ( p p bv)}

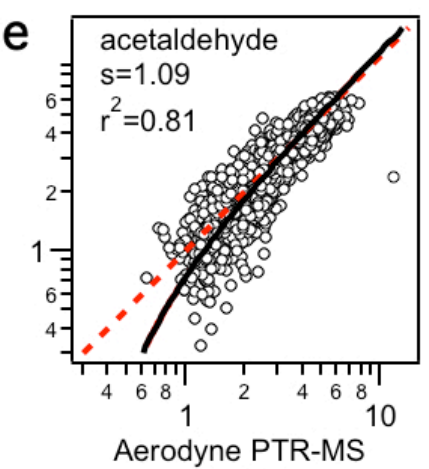

(ppbv)

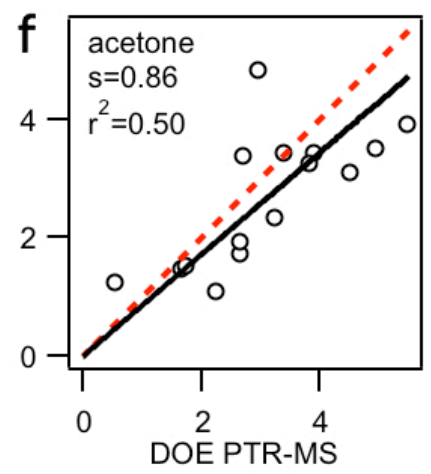

(ppbv)

Fig. 2. Selected results of the comparison of VOC measurements at the T1 site during MILAGRO. Panels (a-c) compare the measurements of the NOAA GC-FID and the UC Irvine canister measurements for the same compound. Panel (d-f) compare measurements made by the NOAA PIT-MS to made from the UC Irvine Ccanisters and by the PTR-MS instruments on the Aerodyne Mobile Laboratory and the DOE G1 aircraft, respectively. Slopes from linear regressions $(s)$ and correlation coefficients, $r^{2}$, for comparisons are tabulated in Table 2.

a particular over flight were averaged and compared to PITMS ground measurements averaged within a window of \pm 10 min from the over flight period. An example of the comparison between surface and airborne measurements is shown in Fig. $2 \mathrm{f}$ for acetone. Due to the low number of data points, linear least-squares fits of the data were constrained to an intercept of zero for these comparisons. Slopes and $r^{2}$ values for fits are shown for all 8 VOCs in Table 2. The inter-comparison is challenging due to: (1) low VOC mixing ratios in a narrow concentration range, (2) the large vertical separation, and (3) short duration of the over-flights. Therefore, correlation coefficients for individual VOCs were low $\left(r^{2}<0.55\right)$, but most species except the $\mathrm{C} 9$-aromatics did not show large systematic differences between the two measurements. Calibration standards were not compared during this study.

\subsection{GC-PIT-MS}

The NOAA PIT-MS was operated in GC-PIT-MS mode seven times during MILAGRO to identify VOCs and evaluate PIT-MS measurements at T1. The GC-interface was similar to that used in a previous study (Warneke et al., 2003); however, the present application is unique in the sense that a chromatogram is obtained at each detection mass of the PITMS. Most GC-PIT-MS analyses occurred early in the day coincident with peak VOC concentrations. Figures 3 and 4 show selected chromatograms from the use of this method for PIT-MS signal attribution. Individual masses of interest are discussed in the following section.

The chromatographic peaks observed at masses 33 (methanol), 45 (acetaldehyde), 59 (acetone), 93 (toluene), 107 (C8-aromatics), and 121 amu (C9-aromatics) were very similar to the results from previous GC-PTR-MS measurements in urban air (Warneke et al., 2003; de Gouw and Warneke, 2007) and provided no evidence of important interferences for any of these compounds.

Acetonitrile is measured by PIT-MS at $42 \mathrm{amu}$. Interferences from the reaction of alkanes and alkenes with $\mathrm{O}_{2}^{+}$ions have previously been observed using GC-PTR-MS (de Gouw et al., 2003; de Gouw and Warneke, 2007). Interferences from propane were evident in GC-PIT-MS chromatograms from Mexico City where mixing ratios of propane reached as high as $250 \mathrm{ppbv}$. From the GC-PIT-MS measurements it is difficult to quantify the sensitivity of the signal at mass $42 \mathrm{amu}$ to propane. However, scatter plots of the signal at $42 \mathrm{amu}$ versus propane showed no correlation between the two measurements. We conclude that while propane 


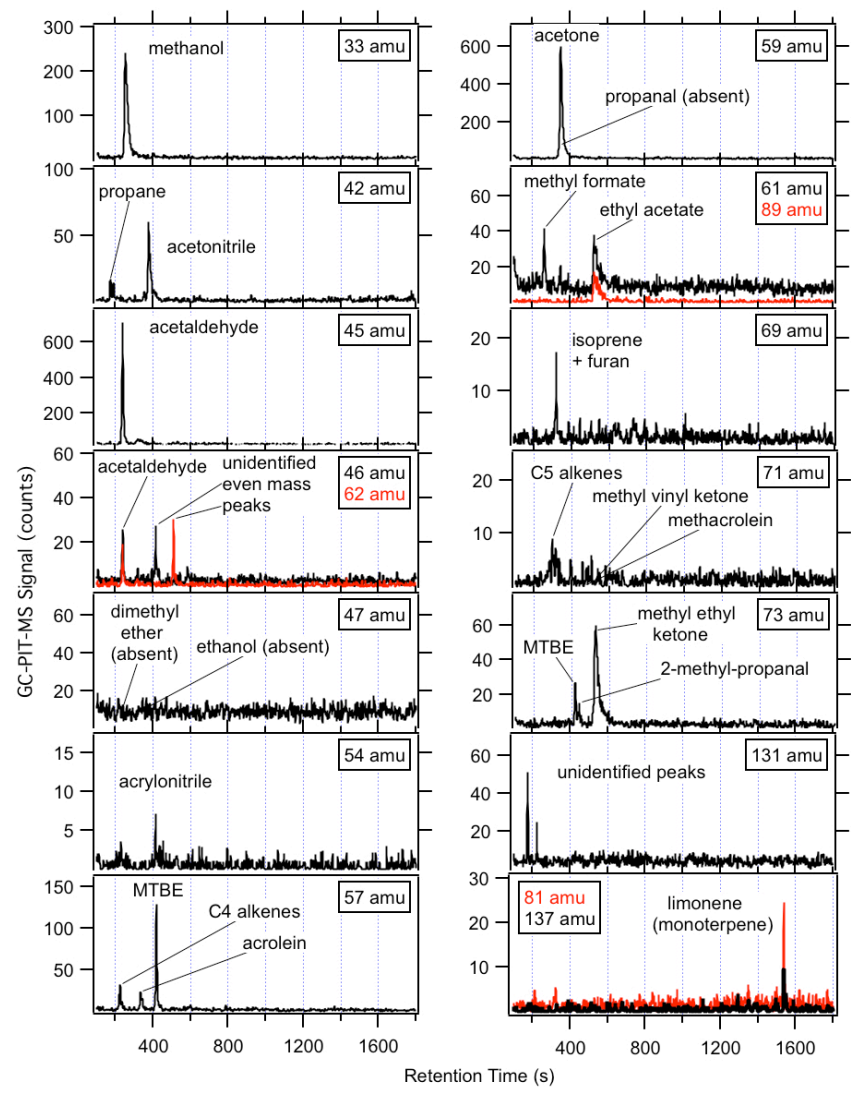

Fig. 3. Select GC-PIT-MS chromatograms obtained during the MILAGRO campaign. Signals reported are sums of six individual chromatograms. The retention time scale is slightly adjusted to be comparable with previously reported values for GC-PTR-MS using the same GC instrument and temperature program (Warneke et al., 2003).

contributed to the signal at $42 \mathrm{amu}$, most of the variability in the 42 amu signal was due to acetonitrile.

Even masses are typically associated with nitrogencontaining compounds in PTR-MS measurements. The chromatogram at $54 \mathrm{amu}$ contained a small peak that is attributed here to acrylonitrile. However, a larger fraction of the signal at $54 \mathrm{amu}$ in on-line measurements comes from $\mathrm{H}_{3} \mathrm{O}^{+}\left(\mathrm{H}_{2} \mathrm{O}\right)_{2}$ clusters at $55 \mathrm{amu}$; water cluster ions show a tail towards lower masses in PIT-MS. Two unidentified evenmass compounds were detected at 46 and 62 amu by GC-PITMS but no conclusive identification was established. Low mixing ratios and isotopic interferences at adjacent masses from more abundant compounds (acetaldehyde and acetic acid respectively) prevent even tentative quantification of these even mass compounds.

Formic acid has previously been reported as the dominant contributor to the PTR-MS signal at $47 \mathrm{amu}$ (Veres et al., 2008). Organic acids do not elute from the GC column used in GC-PIT-MS and therefore cannot be positively iden-

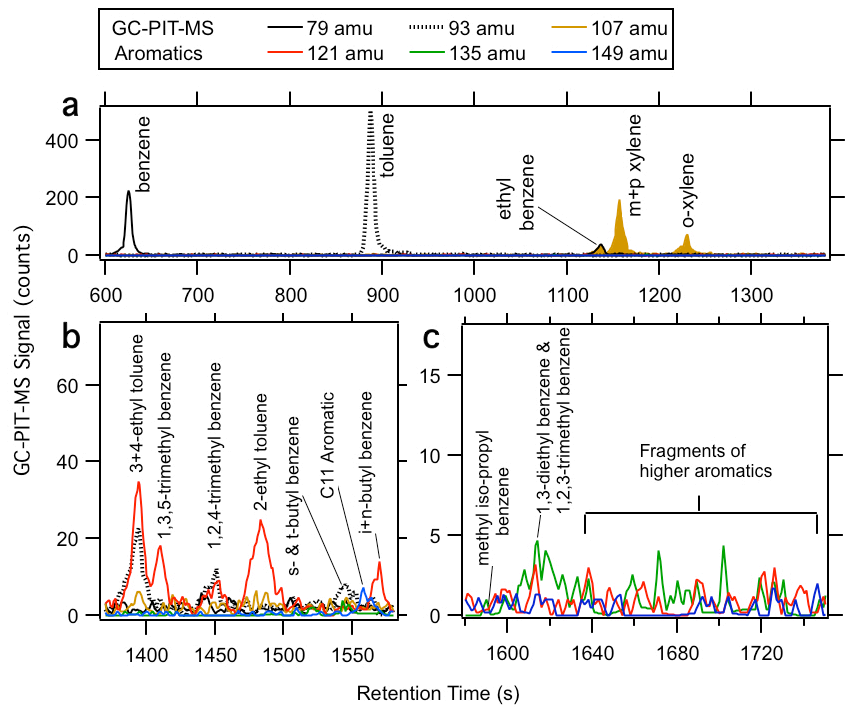

Fig. 4. GC-PIT-MS chromatograms for aromatic measurements from 600-1400 s (a), 1300-1580 s (b) and 1580-1750 s (c). Identifications made after $1300 \mathrm{~s}$ retention time are more uncertain than those for the C6-C8 aromatics.

tified by this technique. However, several other compounds (ethanol, dimethyl ether, and formate esters) are detectable by GC-PIT-MS at $47 \mathrm{amu}$. These compounds did not appear in the chromatograms during MILAGRO and it is unlikely that they are major contributors to the signals on this mass.

The presence of the gasoline additive, methyl tert-butyl ether (MTBE) at $57 \mathrm{amu}$ has been previously observed in field measurements in the United States and Mexico City and confirmed in laboratory studies (Karl, 2003; Warneke et al., 2003, 2005b; Rogers et al., 2006). During MILAGRO, GCPIT-MS confirmed that the signal at $57 \mathrm{amu}$ was dominated by a fragment of MTBE (62\%) with minor contributions from the butenes (multiple peaks, 23\%) and acrolein (15\%), which compounds have been previously observed at this $\mathrm{m} / \mathrm{z}$ in PTR-MS (Fortner and Knighton, 2008). MTBE also interfered (16\%) with the measurement of methyl ethyl ketone (MEK) at 73 amu during the campaign. Previous work has shown that only about $0.2 \%$ of the signal from MTBE appears at its protonated parent ion (89 amu) and GC-PIT-MS showed no evidence of MTBE on this mass.

Acetic acid has been quantified previously at $61 \mathrm{amu}$ using PTR-MS (de Gouw et al., 2003). The chromatogram at $61 \mathrm{amu}$ does not show acetic acid because it does not elute from the column. Two other species were observed in the chromatogram, tentatively identified as methyl formate and ethyl acetate. The latter compound is also observed at $89 \mathrm{amu}$ and has been previously reported in Mexico City (Rogers et al., 2006; Fortner et al., 2009). Ion counts observed at T1 in GC-PIT-MS chromatograms are at least an order of magnitude smaller than those that would be expected from 
PIT-MS online measurements of 1-2 ppbv VOC at 61 amu. We conclude that the online signal at $61 \mathrm{amu}$ is dominated by acetic acid with only minor interference from methyl formate and ethyl acetate.

Isoprene mixing ratios measured from UCI canisters revealed average integrated mixing ratios of about $50 \mathrm{pptv}$ $\pm 100 \%$ but did not show daytime maxima normally associated with biogenic isoprene emissions. A small signal from isoprene was present in GC-FID chromatograms but this compound was not quantified by GC-FID because it was frequently below detection limit. GC-PIT-MS chromatograms did show peaks consistent with extremely small mounts of isoprene ( $69 \mathrm{amu})$, methyl vinyl ketone + methacrolein (71 amu) and one monoterpene (at $81 \mathrm{and} 137 \mathrm{amu}$ ), possibly limonene. Isoprene, however, cannot be separated chromatographically (by GC-PIT-MS) from furan, and the chromatogram at $71 \mathrm{amu}$ also showed contribution from several C5 alkenes. Additionally, measurements at 69 and $71 \mathrm{amu}$ were highly correlated with primary species such as aromatics and alkenes, suggesting that non-biogenic sources dominate these mass signals in the MCMA. We conclude that PTR-MS measurements at masses 69 and 71 are not reliable indicators of biogenic emissions in the MCMA.

The chromatogram at $131 \mathrm{amu}$ revealed the presence of two unknown compounds with relatively short retention times. On-line measurements show large intermittent spikes at this mass that often correlate with peaks (in order of decreasing signal magnitude) at 109, 145, 140, $122 \mathrm{amu}$ and weak signals at numerous masses above $157 \mathrm{amu}$. The origin of this signal is unknown but could be due to a local source of halogenated hydrocarbons. Retention times suggest that these halogenated hydrocarbons, if present, have at least one fluorine substitution. Fragmentation of protonated, high-mass halogenated hydrocarbons in PTR-MS is probable, but poorly characterized and this finding remains speculative.

Signals from aromatic compounds in GC-PIT-MS chromatograms are shown in Fig. 4. Peaks for small aromatics can be clearly identified for benzene ( $79 \mathrm{amu})$, toluene (93 amu), xylene isomers (107 amu), and ethyl benzene. (107 amu). Compound identification consistent with C9 aromatics (121 amu) and some of the C10 isomers (135 amu) can be assigned by retention times with some confidence (Fig. 4b). Some of the peaks in chromatograms at $135 \mathrm{amu}$ and all of those at $149 \mathrm{amu}$ are tentatively identified in Fig. 4c. C11 aromatics probably dominate the signal at $149 \mathrm{amu}$ although the identification of specific peaks remains tentative (Fig. 4).

PIT-MS measurements at $129 \mathrm{amu}$ are reported here as naphthalene: few other hydrocarbons have this molecular mass, and high concentrations of gas-phase naphthalene exceeding $0.3 \mathrm{ppbv}\left(1.5 \mu \mathrm{g} \mathrm{m}^{-3}\right)$ have been previously been reported for Mexico City (Marr et al., 2006). Maximum mixing ratios of naphthalene measured by PIT-MS were as high as $0.8 \mathrm{ppbv}$, however this compound was not calibrated during

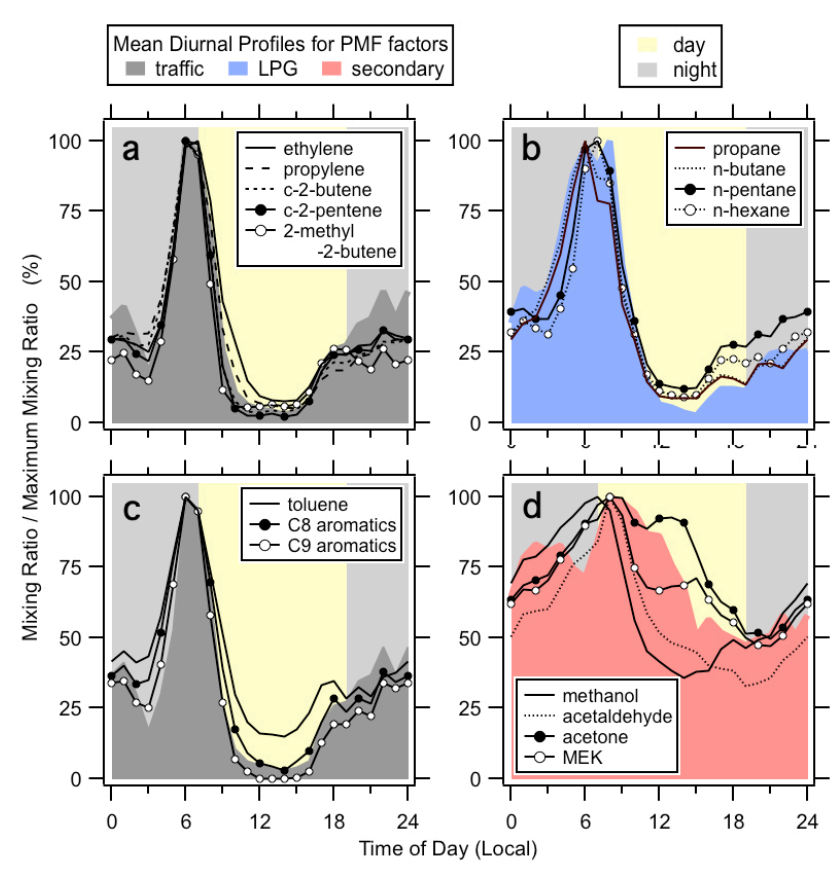

Fig. 5. Measured VOC profiles as a function of local time (UTC $-6 \mathrm{~h}$ ) normalized to the maximum of the mean mixing ratio for individual compounds within chemical families: alkenes (a), alkanes (b), aromatics (c) and OVOCs (d). Normalized mean profiles for PMF factors (FPEAK 0) are shown as shaded areas for each chemical family.

the campaign. GC-PIT-MS has a low sensitivity to naphthalene and it is very likely that ambient levels of naphthalene were below the limit of detection for the method. No peaks were observed in the GC-PIT-MS chromatogram at mass 129.

\section{Results and discussion}

\subsection{Diurnal VOC patterns}

VOC mixing ratios at $\mathrm{T} 1 \mathrm{had}$ a pronounced diurnal pattern during MILAGRO that is summarized graphically by chemical family in Fig. 5. Large, direct emissions and a shallow boundary layer resulted in a maximum concentration for most compounds just before local sunrise (07:00 local time). After sunrise, mixing ratios for primary emissions decreased rapidly due both to photochemical oxidation and dilution into an expanding daytime boundary layer (Fig. 5a-c). Compounds with shorter lifetimes reached their minimum values more quickly and their normalized profile minima were closer to zero. Similar diurnal patterns were evident in the three-factor PMF solution discussed below. 


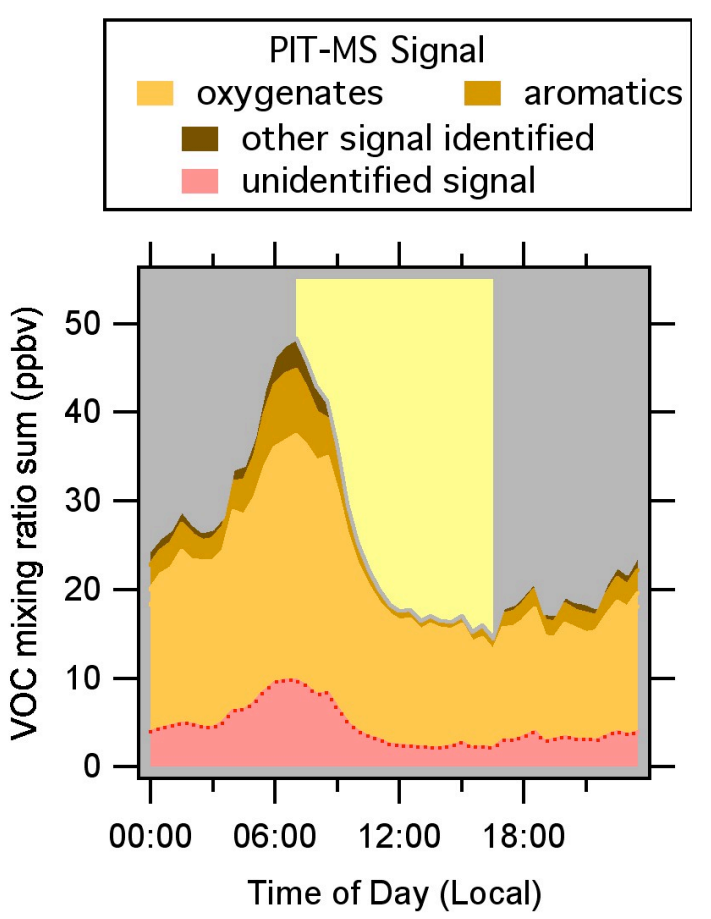

Fig. 6. Average fraction of total PIT-MS signal attributed to oxygenates, aromatics and other identified signal during the MILAGRO campaign. Unidentified signal averages about $18 \%$ of the total.

Photochemical production of oxygenated species leads to a very different diurnal profile. The balance of the production and the dilution in an expanding boundary layer causes mixing ratios for most OVOCs to decline more slowly after sunrise than those with exclusively primary sources (Fig. 5d). The atmospheric processing of primary emissions and production of secondary products is discussed in detail elsewhere (de Gouw et al., 2009).

The fraction of the PIT-MS signal that could not be attributed to specific compounds is shown in Fig. 6 as a function of the time of day. The unidentified signal averaged $18 \%$ of the total for the entire campaign, a result which is consistent with previous estimates of unidentified signal from field measurements with PIT-MS (Warneke et al., 2005b). During the campaign, the majority of PIT-MS signal can be attributed to compounds clearly identified using GC-PIT-MS (Fig. 6).

\subsection{Urban emission ratios}

\subsubsection{Hydrocarbons}

The early morning maximum in most VOCs is due to the accumulation of primary emissions in a shallow boundary layer in the absence of significant chemical removal. Therefore, these data are very useful for the determination of urban emission ratios. Most VOCs with primary sources only (hy- drocarbons) showed a high degree of correlation with inert combustion tracers such as carbon monoxide (CO) (Fig. 7). Most alkenes and aromatics were also strongly $\left(r^{2}>0.70\right)$ correlated with carbon monoxide (Table 3). Propane, nbutane and i-butane correlated poorly with $\mathrm{CO}$, as their emissions are likely dominated by leakage of liquid propane gas (LPG) rather than combustion (Blake and Rowland, 1995). Figure $7 \mathrm{f}$ shows the contrast between morning and afternoon measurements for PIT-MS measurements of the C8aromatics.

Here we derive emission ratios from the slopes of twosided (ODR) fits of the VOC data versus CO. Table 3 summarizes these emission ratios for all measured hydrocarbons. Emission ratios for important VOCs not measured by GCFID or PIT-MS (e.g. ethane, C7 and higher alkanes, and benzene) were calculated from UCI canister measurements of these compounds and CO. In Table 3 we report both the 1sigma uncertainty in the regression slope and the calibration uncertainty. We note that the emission ratios presented here for ethane and propane differ substantially from those calculated by Apel et al. (2010), which were derived from 1sided linear regression fits. Because of the poor correlation of ethane and propane with $\mathrm{CO}$, their ratios versus $\mathrm{CO}$ have a limited value and a very large uncertainty. We are including them here for the sake of completeness.

\subsubsection{Oxygenated VOCs}

Many OVOCs have both direct emission sources and are formed photochemically. In an urban environment, sources of OVOCs from combustion are likely minor compared with those from industrial, evaporative and particularly photochemical sources. As a result, poor correlation with $\mathrm{CO}$ is expected and observed for most OVOCs (Fig. 8). Figure 8 also illustrates the large difference in mixing ratios for OVOCs in the morning and afternoon period. Fits made in the plots of morning OVOC mixing ratios versus $\mathrm{CO}$ tend to parallel the lower edge of the data (closest to the $\mathrm{CO}$ axis) suggesting a method for estimating OVOC measurements that might be useful in future studies.

Emission ratios versus $\mathrm{CO}$ were calculated from slopes of ODR fits for measurements made between 04:00 and 07:00 local time in order to minimize the effects of photochemical production. The results are shown by solid, black lines in Fig. 8 and summarized in Table 4.

\subsubsection{Comparison of emission ratios with those from US cities}

Emission ratios for hydrocarbons versus $\mathrm{CO}$ from measurements made in the United States (Baker et al., 2008; Warneke et al., 2007) are added to Fig. 7 and to Table 3 for comparison purposes. For most alkenes and aromatics, Mexico City emission ratios to $\mathrm{CO}$ are approximately a factor of two larger than corresponding values from the United States. The 
Table 3. Urban emission ratios for non-methane hydrocarbons quantified during MILAGRO versus carbon monoxide are compared to PMFderived emission ratios and values for US cities from the literature. Correlation coefficients $\left(r^{2}\right)$ and the number of points fit $(N)$ are shown for measurement derived emission ratios. Reported errors for measurement-derived emission ratios are $1 \sigma$ uncertainties in the slope of the ODR fit. Uncertainties reported for the PMF-derived emission ratios were calculated using the method described in the text.

\begin{tabular}{|c|c|c|c|c|c|c|c|}
\hline Compound & $\begin{array}{c}\text { MILAGRO } \\
\text { Emission Ratio } \\
\text { Best Estimat } \\
2006 \\
\left(\text { pptv }[\mathrm{ppbv} \mathrm{CO}]^{-1}\right)\end{array}$ & $\begin{array}{c}\text { calibration } \\
\text { uncertainty } \\
\text { (\%) }\end{array}$ & $r^{2}$ & $N$ & $\begin{array}{c}\text { New England } \\
\text { Warneke et al. } \\
(2007) \\
2004 \\
\left(\text { pptv }[\text { ppbv CO }]^{-1}\right)\end{array}$ & $\begin{array}{c}28 \text { US cities } \\
\text { Baker et al. } \\
(2008) \\
1999-2005\end{array}$ & $\begin{array}{l}\text { MILAGRO PMF } \\
\text { Emission } \\
\text { Ratio }^{\mathrm{d}, \mathrm{e}}\end{array}$ \\
\hline \multicolumn{8}{|c|}{ Alkanes } \\
\hline ethane $^{\mathrm{a}}$ & $21.5 \pm 10.8$ & $10 \%$ & 0.50 & 199 & 11.62 & 2.4 & \\
\hline propane $^{\mathrm{b}}$ & $61.7 \pm 15.6$ & $10 \%$ & 0.53 & 1242 & 7.73 & 3.8 & $43.5 \pm 4.1$ \\
\hline n-butane $e^{b}$ & $21.7 \pm 5.0$ & $10 \%$ & 0.57 & 1242 & 1.69 & 1.4 & $17.3 \pm 1.5$ \\
\hline i-butane ${ }^{b}$ & $7.2 \pm 1.6$ & $10 \%$ & 0.57 & 1242 & 1.01 & 0.9 & $6.0 \pm 0.5$ \\
\hline n-pentane ${ }^{b}$ & $2.5 \pm 0.2$ & $10 \%$ & 0.81 & 1241 & 1.55 & 1.2 & $2.6 \pm 0.3$ \\
\hline i-pentane ${ }^{b}$ & $3.3 \pm 0.4$ & $10 \%$ & 0.77 & 1242 & 3.99 & 2.9 & $3.4 \pm 0.4$ \\
\hline n-hexane $e^{b}$ & $1.49 \pm 0.16$ & $10 \%$ & 0.70 & 1240 & 1.07 & 0.6 & $1.0 \pm 0.1$ \\
\hline cyclopentane $^{\mathrm{a}}$ & $0.153 \pm 0.008$ & $10 \%$ & 0.88 & 166 & & & \\
\hline cyclohexane $^{\mathrm{a}}$ & $0.164 \pm 0.008$ & $10 \%$ & 0.77 & 181 & 0.29 & & \\
\hline methyl cyclopentane $\mathrm{a}^{\mathrm{a}}$ & $0.47 \pm 0.02$ & $10 \%$ & 0.87 & 194 & 0.57 & & \\
\hline 2,2-dimethyl butane $\mathrm{e}^{\mathrm{a}}$ & $0.36 \pm 0.02$ & $10 \%$ & 0.89 & 159 & 0.12 & & \\
\hline 2,3-dimethyl butane $\mathrm{a}^{\mathrm{a}}$ & $1.67 \pm 0.13$ & $10 \%$ & 0.72 & 160 & 0.27 & & \\
\hline 2-methyl pentane ${ }^{\mathrm{a}}$ & $1.33 \pm 0.07$ & $10 \%$ & 0.89 & 165 & 1.11 & & \\
\hline 3-methyl pentane $\mathrm{e}^{\mathrm{a}}$ & $0.90 \pm 0.05$ & $10 \%$ & 0.91 & 166 & 1.28 & & \\
\hline $\mathrm{n}$-heptane $\mathrm{a}^{\mathrm{a}}$ & $0.36 \pm 0.06$ & $10 \%$ & 0.69 & 199 & 0.40 & 0.2 & \\
\hline 2,4-dimethyl pentane $\mathrm{a}^{\mathrm{a}}$ & $0.126 \pm 0.006$ & $10 \%$ & 0.87 & 187 & 0.17 & & \\
\hline n-octane $\mathrm{e}^{\mathrm{a}}$ & $0.122 \pm 0.006$ & $10 \%$ & 0.33 & 152 & 0.20 & 0.1 & \\
\hline n-nonane ${ }^{a}$ & $0.065 \pm 0.003$ & $10 \%$ & 0.32 & 158 & & & \\
\hline n-decane ${ }^{a}$ & $0.042 \pm 0.002$ & $10 \%$ & 0.26 & 182 & 1.E-04 & & \\
\hline \multicolumn{8}{|c|}{ Alkenes } \\
\hline ethylene $^{\mathrm{b}}$ & $7.0 \pm 0.4$ & $10 \%$ & 0.90 & 1242 & 4.56 & 4.1 & $7.1 \pm 0.9$ \\
\hline propylene $^{\mathrm{b}}$ & $3.0 \pm 0.2$ & $10 \%$ & 0.86 & 1242 & 1.36 & 1.0 & $2.8 \pm 0.4$ \\
\hline 1-butene ${ }^{b}$ & $0.35 \pm 0.02$ & $10 \%$ & 0.87 & 1236 & 0.14 & 0.2 & $0.32 \pm 0.04$ \\
\hline 2-methyl propene ${ }^{b}$ & $0.85 \pm 0.04$ & $10 \%$ & 0.91 & 1236 & & & $0.76 \pm 0.11$ \\
\hline cis-2-butene ${ }^{b}$ & $0.18 \pm 0.02$ & $10 \%$ & 0.82 & 1236 & 0.06 & & $0.16 \pm 0.02$ \\
\hline trans-2-butene ${ }^{b}$ & $0.20 \pm 0.02$ & $10 \%$ & 0.82 & 1235 & 0.05 & & $0.16 \pm 0.02$ \\
\hline 1-pentene $\mathrm{b}^{\mathrm{b}}$ & $0.152 \pm 0.011$ & $10 \%$ & 0.88 & 1211 & & & $0.15 \pm 0.02$ \\
\hline cis-2-pentene ${ }^{b}$ & $0.100 \pm 0.009$ & $10 \%$ & 0.86 & 1206 & 0.05 & & $0.09 \pm 0.02$ \\
\hline trans-2-pentene ${ }^{b}$ & $0.190 \pm 0.017$ & $10 \%$ & 0.85 & 1209 & & & $0.17 \pm 0.03$ \\
\hline 2-methy 2-butene ${ }^{b}$ & $0.179 \pm 0.019$ & $10 \%$ & 0.83 & 1202 & & & $0.15 \pm 0.02$ \\
\hline 2-methyl 1-butene ${ }^{b}$ & $0.140 \pm 0.011$ & $10 \%$ & 0.87 & 1213 & & & $0.14 \pm 0.02$ \\
\hline 3-methy 1-butene ${ }^{b}$ & $0.044 \pm 0.006$ & $10 \%$ & 0.80 & 1195 & & & \\
\hline 1,3-butadiene ${ }^{\mathrm{a}}$ & $0.278 \pm 0.014$ & $10 \%$ & 0.84 & 147 & & & \\
\hline \multicolumn{8}{|c|}{ Alkynes } \\
\hline acetylene $^{b}$ & $6.5 \pm 0.3$ & $10 \%$ & 0.90 & 1242 & 3.60 & 3.4 & $5.0 \pm 0.7$ \\
\hline \multicolumn{8}{|c|}{ Aromatics } \\
\hline benzene $^{a}$ & $1.21 \pm 0.06$ & $10 \%$ & 0.94 & 183 & 0.62 & 0.7 & \\
\hline toluene ${ }^{\mathrm{c}}$ & $4.2 \pm 0.4$ & $20 \%$ & 0.69 & 2563 & 2.62 & 2.7 & $4.0 \pm 0.4$ \\
\hline$\Sigma \mathrm{C} 8$ aromatics $^{\mathrm{c}}$ & $4.3 \pm 0.6$ & $50 \%$ & 0.71 & 2563 & 1.93 & & $3.8 \pm 0.5$ \\
\hline$\Sigma 9$ aromatics $^{\mathrm{c}}$ & $2.8 \pm 0.6$ & $50 \%$ & 0.79 & 2563 & 1.07 & & $2.3 \pm 0.4$ \\
\hline$\Sigma \mathrm{C} 10$ aromatics $^{\mathrm{c}}$ & $0.76 \pm 0.15$ & $50 \%$ & 0.71 & 2563 & & & $0.60 \pm 0.14$ \\
\hline$\Sigma 11$ aromatics $^{c}$ & $0.16 \pm 0.03$ & $50 \%$ & 0.41 & 2563 & & & $0.12 \pm 0.01$ \\
\hline naphthalene $\mathrm{c}^{\mathrm{c}}$ & $0.12 \pm 0.01$ & $50 \%$ & 0.24 & 2592 & & & $0.11 \pm 0.01$ \\
\hline
\end{tabular}

\footnotetext{
${ }^{a}$ UCI-canisters, data from entire campaign.

b NOAA GC-FID, data from entire campaign.

c NOAA PIT-MS, data from 04:00-07:00 a.m., local time.

d Calculated using $\Sigma$ (traffic + LPG) factors; $r^{2}=0.86$ with CO for PMF traffic factor and $r^{2}=0.56$ for LPG factor.

e $N=851$ for emission ratios derived from PMF analysis.
} 
Table 4. Urban emission ratio estimates versus CO for OVOCs and acetonitrile calculated by linear regression and from MILAGRO measurements and from the results of PMF analysis. For comparison, literature values from PTR-MS measurements made in New England and from a US tunnel study are also shown. Methods used to calculate these values are discussed in detail in the text. Also shown are correlation coefficients $\left(r^{2}\right)$ and the number of points fit $(N)$. Reported errors for measurement-derived emission ratios are $1 \sigma$ uncertainties in the slope of the ODR fit. Uncertainties reported for the PMF-derived emission ratios were calculated using the method described in the text.

\begin{tabular}{|c|c|c|c|c|c|c|c|c|c|c|}
\hline & \multirow{2}{*}{$\begin{array}{c}\text { MILAGRO } \\
\text { Emission Ratio } \\
\text { Best estimate } \\
2006^{\mathrm{a}} \\
\text { (pptv [ppbv CO}]^{-1} \text { ) }\end{array}$} & \multirow{2}{*}{$\begin{array}{c}\text { calibration } \\
\text { uncertainty } \\
(\%)\end{array}$} & \multirow[t]{2}{*}{$r^{2}$} & \multirow[t]{2}{*}{$N$} & \multirow{2}{*}{$\begin{array}{c}\text { New England } \\
\text { Warneke et al. } \\
(2007) \\
2004 \\
\left(\text { pptv }[\text { ppbv CO }]^{-1} \text { ) }\right.\end{array}$} & \multicolumn{4}{|c|}{$\begin{array}{c}\text { Caldecot Tunnel } \\
\text { Ban-Weiss et al. (2008) }\end{array}$} & \multirow{2}{*}{$\begin{array}{l}\text { MILAGRO PMF } \\
\text { Emission } \\
\text { Ratio }^{\mathrm{b}, \mathrm{d}}\end{array}$} \\
\hline & & & & & & 1999 & 2001 & 2006 & Diesel & \\
\hline \multicolumn{11}{|c|}{ Oxygenates } \\
\hline methanol & $2.1 \pm 0.5$ & $20 \%$ & 0.11 & 2563 & 4.0 & & & & & $6.1 \pm 2.1$ \\
\hline acetaldehyde & $1.0 \pm 0.3$ & $20 \%$ & 0.23 & 2563 & 0.7 & 1.0 & 0.5 & 0.7 & 12.0 & $2.0 \pm 0.9$ \\
\hline formic acid ${ }^{c}$ & $0.22 \pm 0.11$ & $50 \%$ & 0.12 & 2592 & & & & & & $0.4 \pm 0.3$ \\
\hline acetone & $0.51 \pm 0.13$ & $20 \%$ & 0.06 & 2563 & 2.9 & 0.7 & 0.4 & & & $1.0 \pm 1.0$ \\
\hline acetic acid & $0.5 \pm 0.2$ & $50 \%$ & 0.09 & 2563 & & & & & & $0.5 \pm 0.5$ \\
\hline MEK & $0.29 \pm 0.07$ & $20 \%$ & 0.13 & 2563 & 0.8 & 0.1 & 0.1 & 0.2 & 1.4 & $0.5 \pm 0.3$ \\
\hline \multicolumn{11}{|c|}{ Other } \\
\hline acetonitrile & $0.27 \pm 0.07$ & $20 \%$ & 0.24 & 2563 & & & & & & $0.4 \pm 0.1$ \\
\hline
\end{tabular}

a Ratios calculated from PIT-MS data collected between 04:-07:00 a.m. LT.

b Calculated using $\Sigma$ (traffic + LPG) factors; $r^{2}=0.86$ with CO for PMF traffic factor and $r^{2}=0.56$ for LPG factor.

${ }^{\mathrm{c}}$ For purposes of PMF, formic acid was included as one of the 65 unquantified PIT-MS measurements.

${ }^{\mathrm{d}} N=851$ for PMF-derived emission ratios.

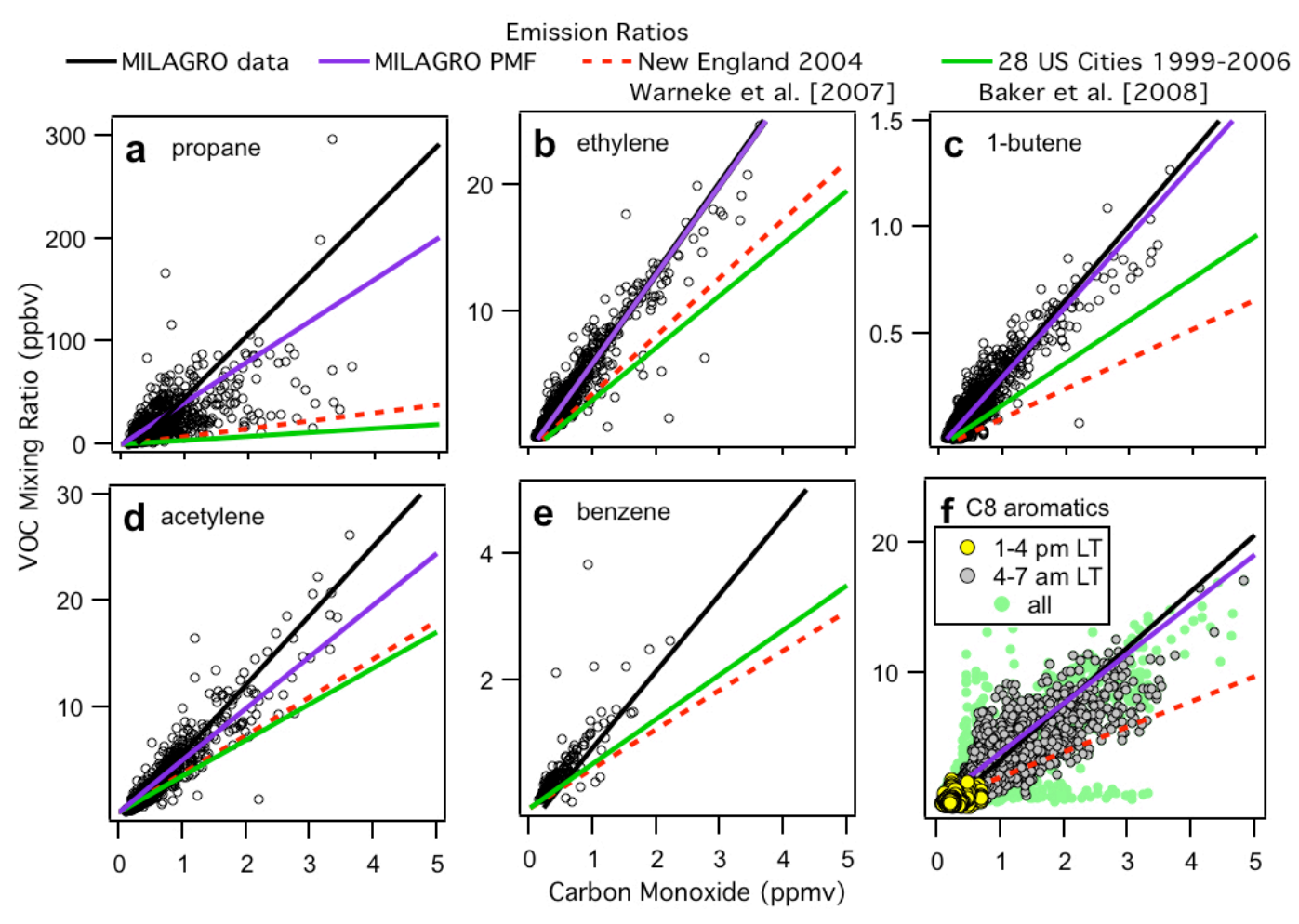

Fig. 7. Selected plots used to calculate urban emission ratios (ERs) with respect to carbon monoxide (CO) for VOC measurements made by GC-FID (a-d), canister samples (e) and PIT-MS (f). Urban ERs calculated from measurements using ODR fits (black) and Positive Matrix Factorization results (purple) during MILAGRO. MCMA ERs are compared to literature values (red, green) obtained for cities in the United States. PIT-MS measurements are shown on a 1-minute time base (f) to highlight mixing ratio differences prior to local sunrise (grey) versus those observed during the mid-afternoon (yellow). PMF lines represent ERs obtained by summing the traffic and LPG factors. 

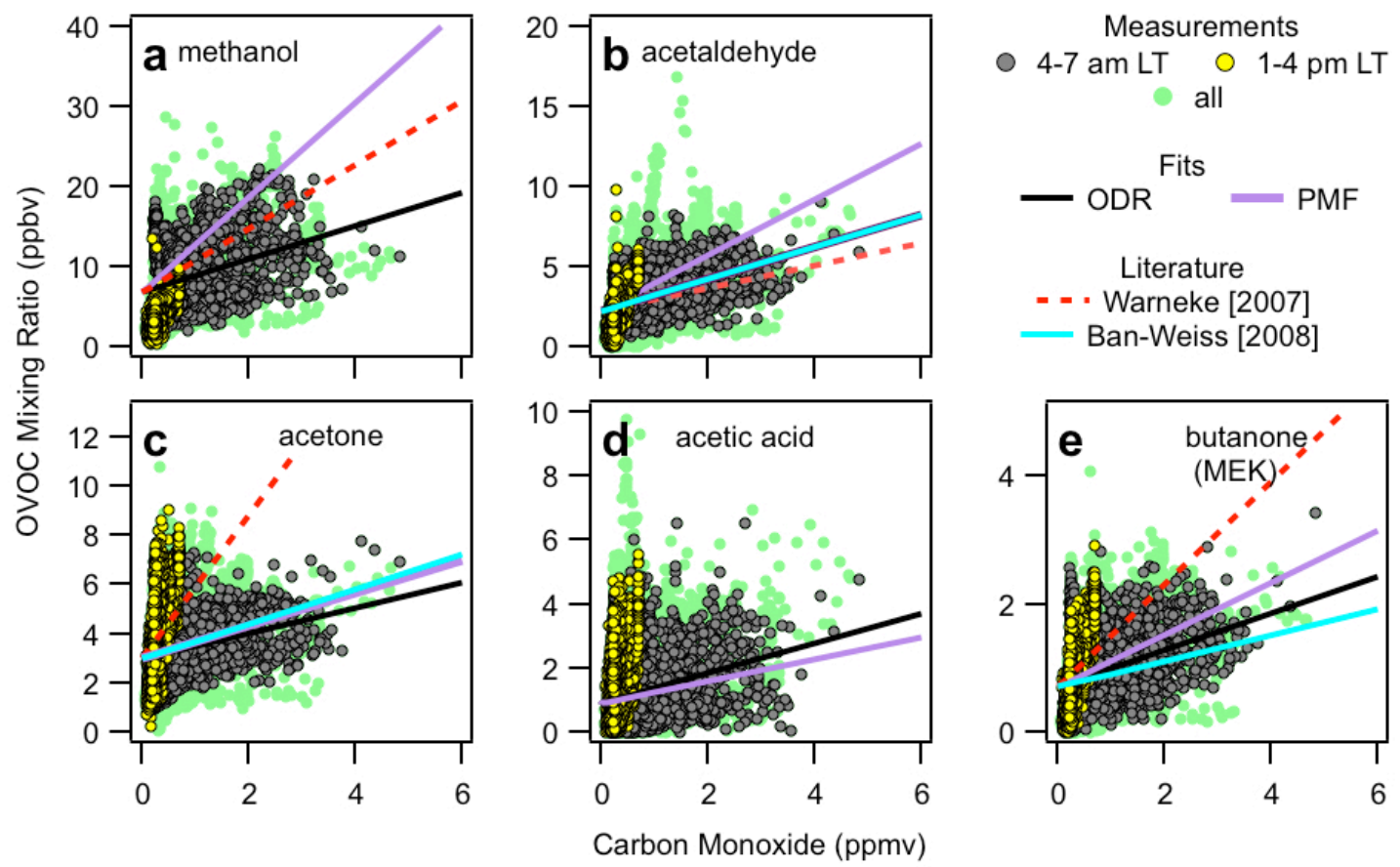

Fig. 8. Plots used to calculate emission ratios with respect to carbon monoxide (CO) for 5 OVOCs quantified by PIT-MS. Emission ratios calculated from measurements using 2-sided regression fits (black) and Positive Matrix Factorization results (purple) during MILAGRO are compared to literature values obtained during field studies in New England (red) and to a California tunnel study (blue). 1-Minute PITMS data show afternoon enhancements in OVOCs typically observed during the campaign. For comparison purposes, lines showing PMF and literature ERs are shown with intercepts obtained from ODR fits of MILAGRO measurements. PMF lines represent ERs obtained by summing the traffic and LPG factors.

difference is probably due to differences in automobile emission systems and fleet ages between the two countries. $\mathrm{CO}$ to $\mathrm{CO}_{2}$ ratios of about $45 \mathrm{ppbv} \mathrm{ppmv}^{-1}$ were observed during the MILAGRO campaign (Vay et al., 2009); a value similar to the ratio observed in plumes originating in China and twice as large as the $10-20$ ppbv ppmv $^{-1}$ observed in industrialized nations like Japan and the United States (de Gouw et al., 2004; Takegawa et al., 2004). It is worth noting, therefore, that VOC emission ratios per $\mathrm{kg}$ fuel burned are probably closer to a factor of $6 \pm 2$ larger in Mexico City than those for US cities.

Emission ratios for OVOCs from 2004 measurements in New England and those from a 1999 California tunnel study are shown in Fig. 8 and Table 4 (Warneke et al., 2007; BanWeiss et al., 2008). OVOC emission ratios for Mexico City more closely resemble values obtained in the tunnel study than those calculated from measurements in the Northeastern US Differences between OVOC emission ratios from the MCMA and the Northeastern US could be due to sampling methodology, i.e. the Northeastern US data were largely collected outside city boundaries and although an attempt was made to account for the effects of secondary production using a photochemical lifetime method, the resulting emission ratios may still overestimate the direct emissions. Biogenic emissions may also account for some of the differences ob- served between Mexico City and New England, particularly for methanol, which has significant biogenic sources (Jacob, 2005; Millet et al., 2008).

\subsection{PMF Results}

\subsubsection{The PMF solution}

PMF solutions with 1 to 7 factors were examined using the method described in Sect. 2.3. A three-factor solution was chosen based on the plausibility of the results, with factors identified as traffic, LPG leakage, and secondary + long-lived species, described individually in more detail below. This solution has $Q / Q_{\exp }=4.07$ at FPEAK 0, which suggests that the errors may be somewhat underestimated or that there is substantial variability in the dataset that cannot be modeled well with a few fixed chemical profiles. $Q / Q_{\text {exp }}$ increases by less than $10 \%$ over the range in FPEAK from -5 to +5 . Over the narrower FPEAK range from -3 to $+3, Q / Q_{\text {exp }}$ increases by $2 \%$ compared to the FPEAK 0 solution. Measurements from each instrument contributed $44 \pm 0.1 \%$ (GCFID) and $56 \pm 0.1 \%$ (PIT-MS) to the parameter $(Q)$ over the range from FPEAK -3 to +3 . About $20 \%$ of the value of $Q$ could be attributed to unidentified PIT-MS signal. 
GC-FID

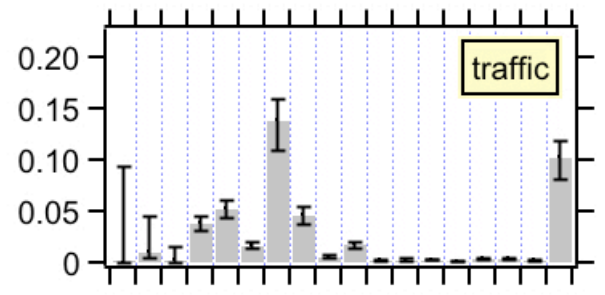

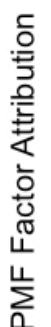

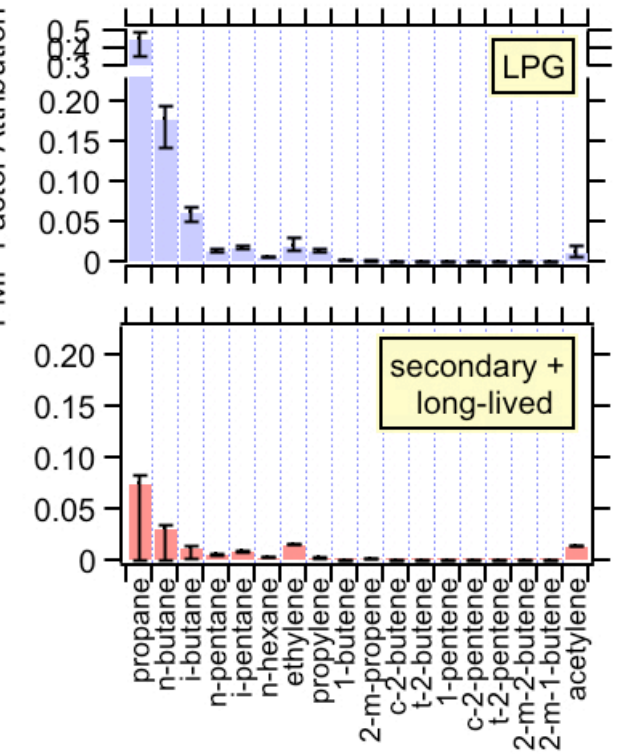

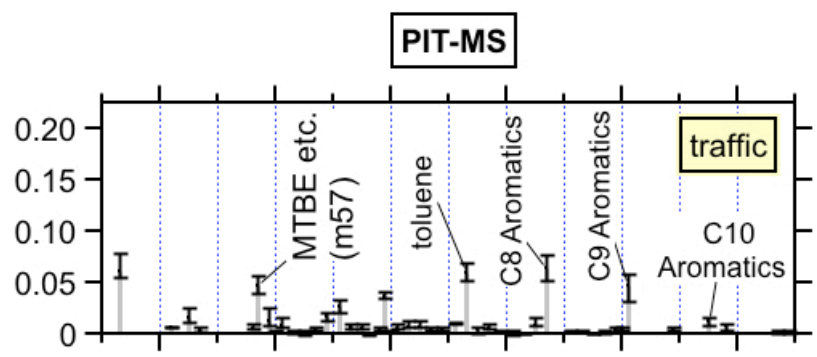
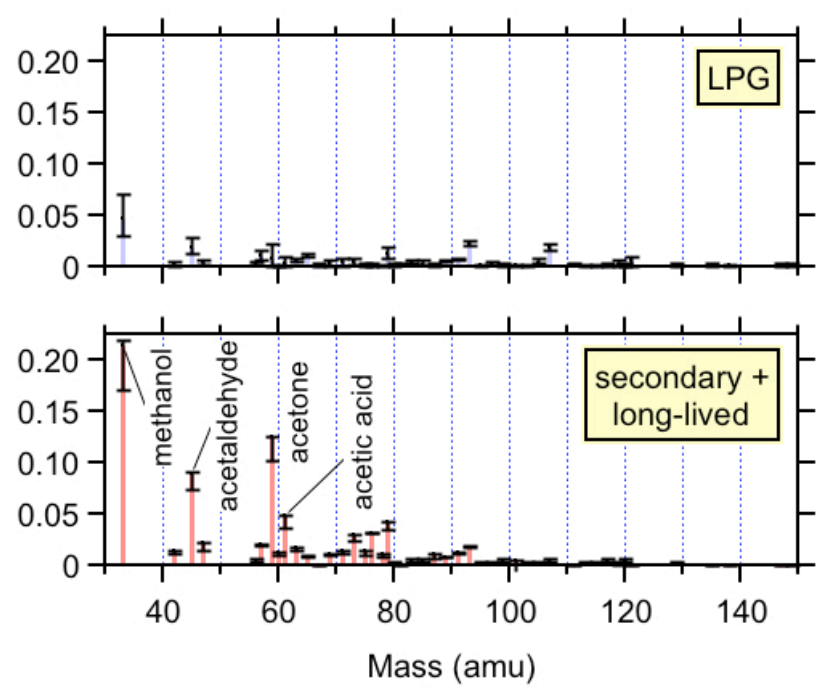

Fig. 9. PMF profiles are shown for compounds measured by the NOAA GC-FID (left column) and NOAA PIT-MS (right column) for the three factors, here labeled traffic, LPG, and secondary + long-lived species. Error bars represent the variation in PMF factors from the FPEAK 0 solution (solid bars) over the FPEAK range from -3.0 to +3.0 as described in the text.

Source profiles for the 3-factor solution are shown in Fig. 9. The first factor, referred to as "traffic" from now on, is comprised of hydrocarbons including highly reactive species and was easily recognized as the VOCs observed during the early-morning maximum. The profile of the second factor, named "LPG," contains propane and other small alkanes and is likely associated with LPG leakage. The third factor is named "secondary + long-lived species" and is comprised of inert hydrocarbons and oxygenated species, and resembles the VOCs observed in more processed air masses observed during the day. In PMF solutions with 4 or more factors, additional factors resembled combinations of the three factors and did not provide additional insight into the data. Despite the presence of gas-phase chemical tracers for biogenic emissions (e.g. isoprene), biomass burning (e.g. acetonitrile), and known industrial emissions within the MCMA (Fortner et al., 2009), no factors were identified in the PMF analysis that were direct representations of these emission sources during this study. A more detailed individual description of the three factors can be found below.

Figure 10 shows the variability in apportionment of a few important VOCs over the range of FPEAKS -3 to +3 . Changes in the apportionment of individual compounds with
FPEAK have no clear physical interpretation. For example, the apportionment of $n$-butane to the three factors changes sharply at FPEAKS above +1.5 , where $n$-butane is attributed almost completely to the LPG factor, consistent with its expected source from LPG leakage as discussed above; however, the apportionments at FPEAKs less than -0.5 , with significant contributions of n-butane to the traffic and secondary + long-lived species is also plausible and consistent with the lifetime of $\mathrm{n}$-butane and its emissions in vehicle exhaust. Acetone shows an opposite behavior with respect to FPEAK, where solutions with FPEAK greater than +2 apportion acetone exclusively to the secondary + long-lived species factor, which does not reflect its known sources from traffic. Thus, no single FPEAK value produces a solution that is uniquely best. Therefore, the solutions presented herein are for FPEAK 0 with the range of solutions with FPEAK of \pm 3 are reported as an estimate of the uncertainty in the factor profiles and time series. We speculate that some of the variability in apportionment with FPEAK in this analysis is explained by the lack of strong contrast in the time trends of different species during the night when all direct emissions accumulate in the shallow boundary layer and chemical processing of the air mass is at its daily minimum. 

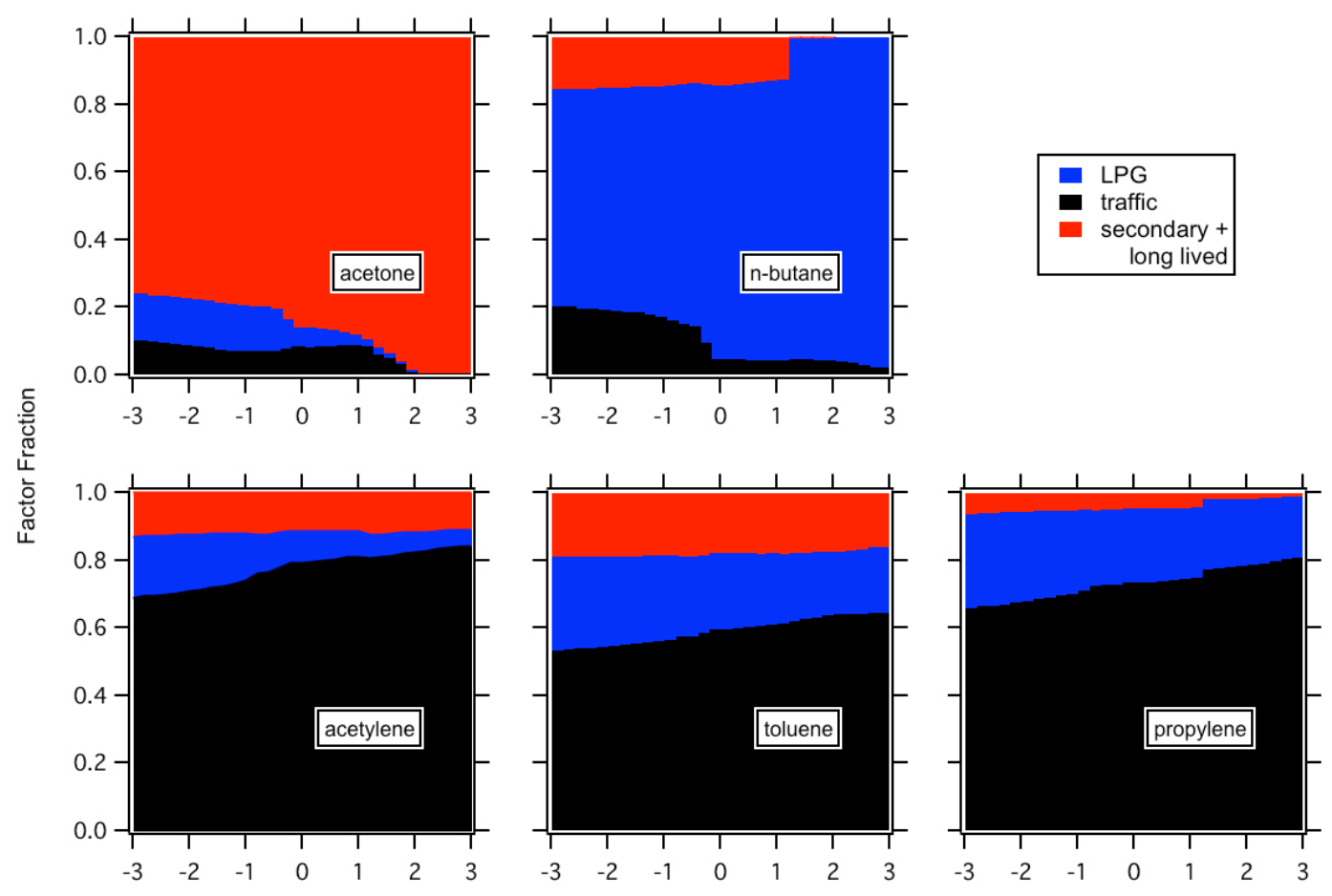

FPEAK

Fig. 10. Variability in apportionment to factors as a function of the PMF rotational parameter FPEAK for acetone, n-butane and three hydrocarbons dominated by traffic emissions (acetylene, toluene and propylene). The change in the PMF quality of fit parameter is less than $2 \%$ for the FPEAK values shown.

Other methods used to estimate uncertainties in the analyses, e.g. bootstrapping and seed variation (Ulbrich et al., 2009), were investigated but gave smaller variation in factor profiles. The three-factor solution was investigated as a function of the weighting errors assumed for the GC-FID and PIT-MS data. None of the observed variation changed the conclusions drawn here in any significant way. A more comprehensive analysis of the effects on PMF analysis of relative weighting of the data from different instruments can be found elsewhere (Slowik et al., 2010).

The averaged diurnal variation in the factor time series is shown in Fig. 11. Briefly, the traffic factor consists of aromatics, alkenes, alkanes and acetylene, and is at its maximum in the early morning. The LPG factor consists predominantly of propane, $n$-butane and i-butane and also has a maximum in the morning. The secondary + long-lived species factor is at its maximum about $2 \mathrm{~h}$ later than the traffic factor and falls off much more slowly after sunrise. The averaged diurnal variations in factor time series were overlaid with the VOC data in Fig. 5. The traffic factor closely follows the diurnal variations in the more reactive alkenes and aromatics. The LPG factor is very similar to the measured diurnal variations in propane and other alkanes. The secondary + long-lived species factor does not directly match the diurnal variation of any single oxygenated species, but approximates the ensemble average diurnal variation of the oxygenated species shown.
The PMF reconstructions of the time series of selected VOCs are shown for acetylene, n-butane and acetone at FPEAK 0 in Fig. 12. The variability in acetylene measurement is well described by the PMF time-series reconstruction $\left(r^{2}=0.89\right)$ and the majority of this compound is attributed to traffic sources. The variability in n-butane is also reasonably well described by the PMF time-series reconstruction $\left(r^{2}=0.76\right)$. In this case, most of the signal is attributed to LPG leakage. The measurement of acetone and its PMF time-series reconstruction (Fig. 12c) correlate well $\left(r^{2}=0.93\right)$ and most of the signal is attributed to the secondary + long-lived species factor with a smaller contribution from the traffic factor. Large residuals between measured and reconstructed concentrations were frequently correlated with simultaneous spikes in several VOCs without corresponding changes in $\mathrm{CO}$ mixing ratios. Examples of such spikes can be seen in Fig. 12 for acetylene and n-butane and they suggest the presence of local emissions, the variability of which is difficult to capture with PMF if the plume composition is sufficiently different from the dominant sources of variation.

Time series reconstructions for other species were compared to the measurements (results not shown here). Linear correlation coefficients were high for $\mathrm{C} 7-\mathrm{C} 10$ aromatics, alkenes and acetylene $\left(r^{2}>0.85\right)$ and slightly lower for methanol, acetone, acetaldehyde and MEK $(0.82<$ $\left.r^{2}<0.90\right)$. PMF reconstructions for alkanes and the 


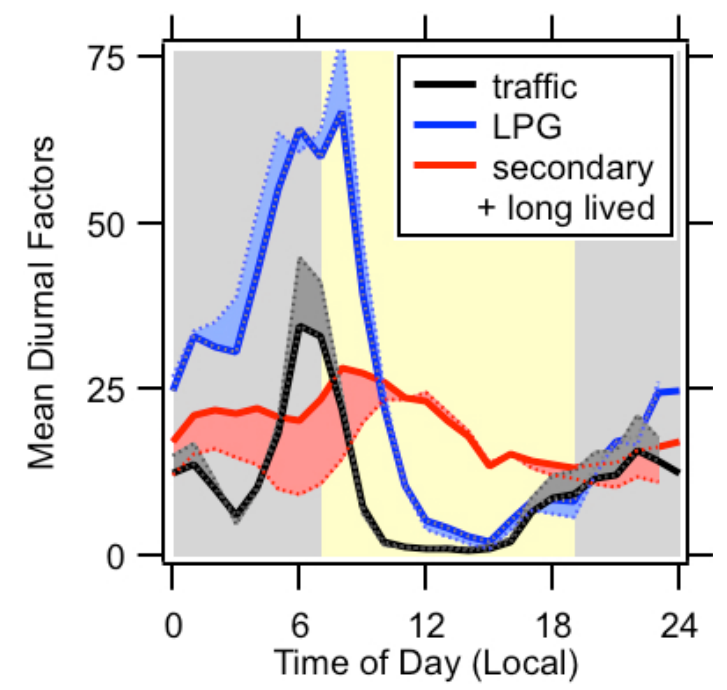

Fig. 11. Mean diurnally averaged profiles for the 3-factor PMF solution obtained from MILAGRO VOC measurements. Solid lines represent the mean diurnal profile for each factor at FPEAK 0 while the shaded regions bordered with dashes show the variation from the FPEAK 0 solution over the FPEAK range from -3.0 to +3.0.

C11-aromatics correlated reasonably well with measurements $\left(0.60<r^{2}<0.88\right)$. Much lower correlations were found for acetonitrile $\left(r^{2}=0.42\right)$, acetic acid $\left(r^{2}=0.48\right)$, and naphthalene $\left(r^{2}=0.55\right)$. Correlations for these species did not improve significantly even when PMF solutions with greater than three factors were considered $(p>3)$. Poor fits for these compounds in the PMF analysis suggest that they have important sources that are not correlated with the three factors identified here. For acetonitrile, the explanation may be the presence of biomass burning sources (de Gouw et al., 2009) that were not identified as a separate factor in the PMF analysis.

\subsubsection{PMF traffic factor}

The profile of the traffic factor is shown in Fig. 9 (top panels). The profile is dominated by alkenes and aromatics. C5 and higher alkanes are also present. The only OVOC with significant partitioning to the traffic factor was methanol. Methanol mixing ratios were substantial during MILAGRO and have likely contributions from tailpipe and other vehicular sources previously observed by vehicle emission studies in the MCMA (Rogers et al., 2006) or by industrial sources.

The PIT-MS product-ion signal at $57 \mathrm{amu}$ was predominantly apportioned to the traffic factor, which is consistent with the major contribution of the gasoline additive MTBE to m57 ( 80\%), as determined by GC-PIT-MS (Fig. 3). Other product ion signals with significant presence in the traffic factor are at 69, 71, 83 and $85 \mathrm{amu}$. The signals at 69 and $71 \mathrm{amu}$ are typically used to quantify isoprene and its photoproducts MVK and methacrolein in PTR-MS. This analy- sis suggests that the importance of other species with trafficrelated sources (such as the presence of C5-alkenes at $71 \mathrm{amu}$ shown in Fig. 3) at these masses in Mexico City can be shown with PMF analysis. The absence of a PMF factor representing biogenic emissions for compounds measured at $\mathrm{m} / z 69$ and 71 by PIT-MS is consistent with the observations about the signal at these masses (e.g. low mixing rations, correlation with CO and GC-PIT-MS results) discussed elsewhere in this text.

\subsubsection{PMF LPG factor}

The LPG factor profile is dominated by the three light alkanes (propane, n-butane and i-butane) associated with liquefied petroleum gas use in the MCMA (Fig. 9, middle panel) (Blake and Rowland, 1995; Vega et al., 2000; Velasco et al., 2007). The reconstruction of $n$-butane in the 3 -factor PMF solution is compared with its measurement in Fig. 12 (middle panel). The three major LPG alkanes also contribute to the traffic factor, possibly because LPG is used as a vehicle fuel (Diaz et al., 2000), and also to the secondary + long-lived species factor, due to their lower reactivity with the hydroxyl radical $\left(k_{\mathrm{OH}}\right)$ as discussed below. However, the contribution of propane to these factors is strongly dependent on FPEAK (Fig. 10) and therefore not well-quantified by this analysis.

Other compounds apportioned to this factor include other light alkanes, some traffic-related VOCs and methanol, but the amount of signal associated with the LPG factor for these other VOCs decreases as a function of FPEAK. The diurnally averaged profile for the LPG factor has a similar shape to that of the traffic factor, but has a larger magnitude and wider morning maximum (Fig. 11) probably due to the longer photochemical lifetime of major LPG species.

\subsubsection{PMF secondary + long-lived species factor}

The profile for the secondary + long-lived species factor consists of mostly oxygenated compounds: methanol, acetone, acetaldehyde, acetic acid, methyl ethyl ketone (MEK), and formic acid. For all quantified OVOCs except acetic acid, at least $66 \%$ of the measured concentration was explained by this factor. Good agreement was found between PMF reconstructions and measurements of methanol, acetone, acetaldehyde, and butanone (MEK) (slopes $>0.90$ and $r^{2}>0.80$ ). Although acetic acid, formic acid and acetonitrile received majority apportionment to the secondary + long-lived species factor, measurements of these compounds correlated poorly $\left(r^{2}<0.50\right)$ with PMF reconstructions. Variation in the mixing ratios of these 3 compounds were not well explained by the PMF analysis. These results could suggest additional sources for these compounds. However, instrument precision also limits the degree of correlation for these species.

The relative contribution to the secondary + long-lived species factor increased with FPEAK for all quantified OVOCs and acetonitrile. Because OVOCs have known 

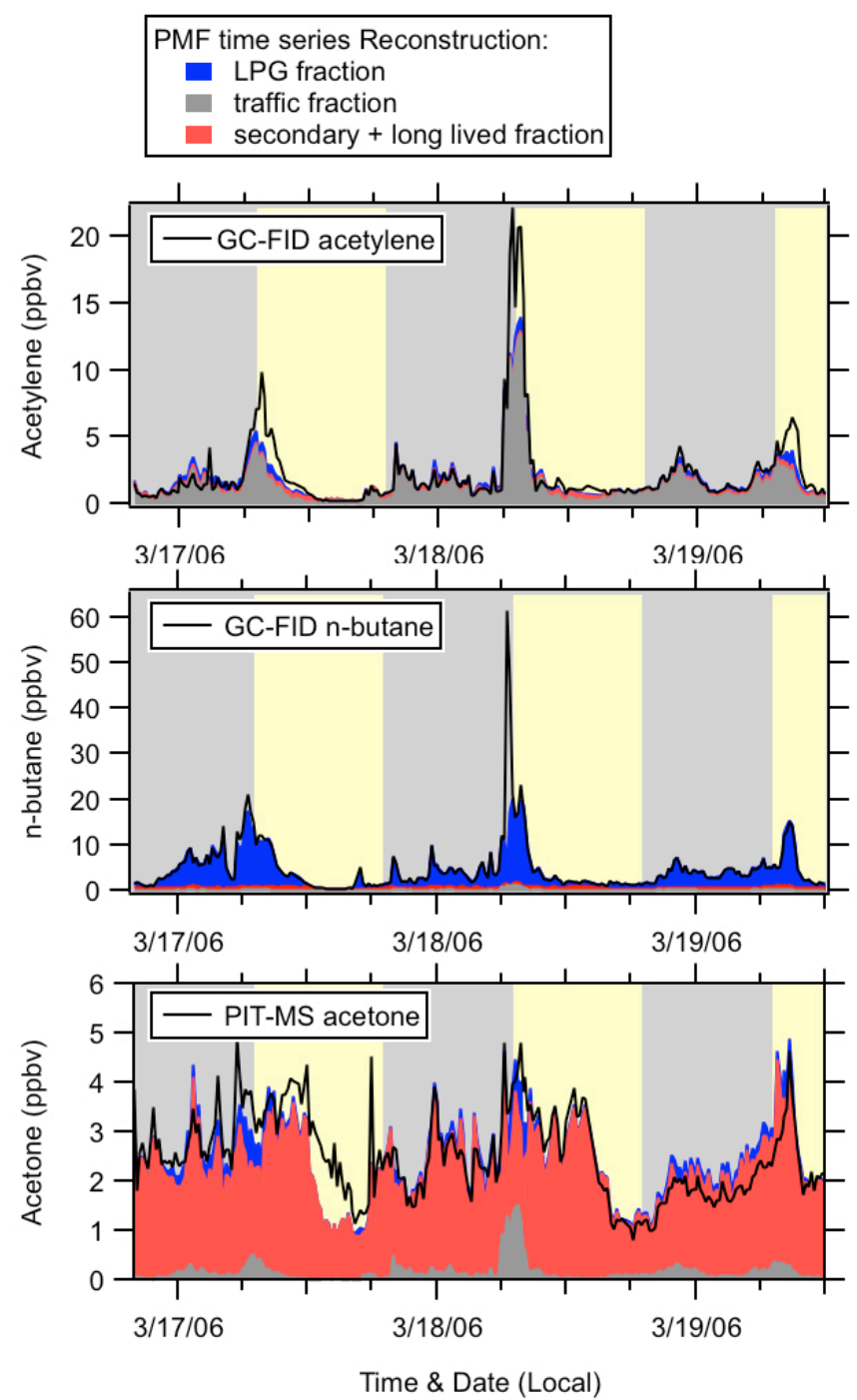
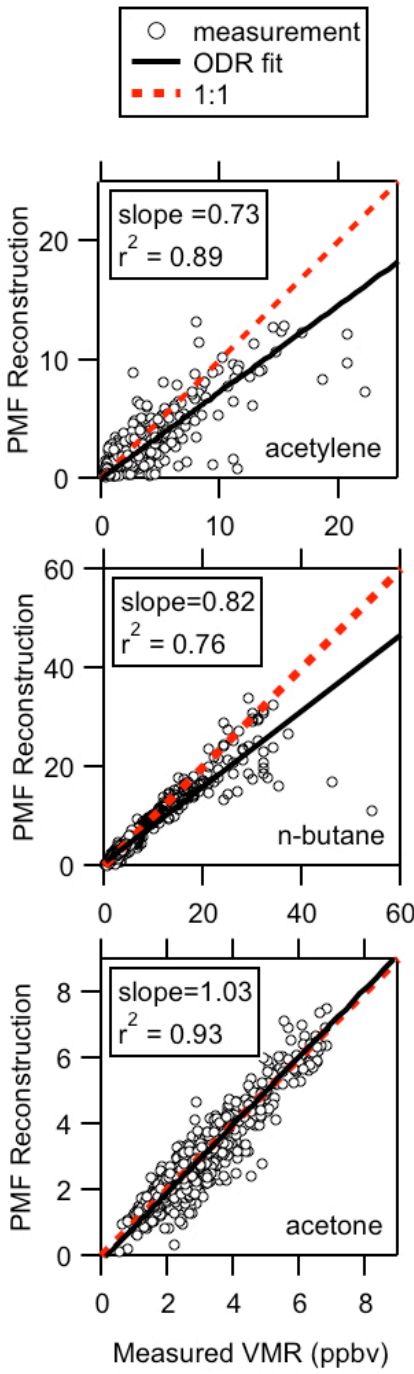

Fig. 12. Selected comparisons between measurements and PMF reconstructions for one period during the MILAGRO campaign. The left column shows time series for representative compounds with dominant apportionment to the traffic factor (acetylene), the LPG factor (nbutane) and the secondary + long-lived factor (acetone). Measurements are shown as solid black traces for comparison. On the right are scatter plots of PMF reconstructions (FPEAK 0) versus measurements showing single-sided fits (black) and 1:1 lines (red) for the same compounds.

vehicular emission sources (Rogers et al., 2006), the near absence of OVOCs from the traffic factor at FPEAKS $>2.0$ provides a physical constraint on the results of PMF analysis. An example such a change in the apportionment of an OVOC is shown for acetone in Fig. 10.

A comparison of measurements and PMF reconstructions for acetone are shown in Fig. 12 (bottom left panel). The diurnal average for the PMF secondary + long-lived factor looks similar to the measured diurnal profiles of OVOCs (Fig. 5d), although diurnally averaged measurements of OVOCs show considerably more variation as a group than do hydrocarbons.
PIT-MS product-ion signals at masses $75,87,89$, and 101 amu were mainly attributed to the secondary + long-lived factor. This suggests the presence of OVOCs at these masses. Specifically, it is possible that propanoic and butanoic acids contributed to the signal at masses 75 and 89 .

\subsubsection{Estimation of VOC emission ratios using PMF results}

Linear regression (ODR) of individual PMF factors plotted versus $\mathrm{CO}$ showed that the traffic factor correlated well with $\mathrm{CO}\left(r^{2}=0.86\right)$ in the predawn period but showed no correlation after noon.The LPG and secondary + long-lived species factors showed poor correlation with $\mathrm{CO}$ in the morning but 
stronger correlations in the afternoon $\left(r^{2}=0.81,0.77\right.$ respectively). To estimate urban emission ratios for VOCs and OVOCs in the MCMA from the PMF results, the sum of the contributions of the traffic and LPG factors were plotted against $\mathrm{CO}\left(r^{2}<0.42\right)$ measurements for the 30 compounds quantified and reported during the campaign plus formic acid $(\mathrm{m} / \mathrm{z}$ 47). The slopes of the resulting plots are presented in Tables 3 and 4 for VOCs and OVOCs respectively.

The relative uncertainties $(1 \sigma)$ in the slopes of the linear regression used to calculate PMF-derived emission ratios were small (1-3\%) for all compounds. Uncertainty in PMFderived emission ratios was also assessed using changes in apportionment as a function of the PMF FPEAK parameter. The maximum relative difference in apportionment from FPEAK 0 over the range from FPEAK -3 to 3 for the sum of the traffic and LPG source profiles was larger (4\%-100\%) than the regression uncertainty for all compounds. The sum of the relative uncertainties for each compound were used to calculate the absolute uncertainties in PMF-derived emission ratios shown in Tables 3 and 4.

Emission ratios calculated from PMF results are compared to values calculated directly from VOC measurements in Fig. 13. Individual points represent VOC species and are colored according to the PMF factor that explained the majority of the variation of that species. Emission ratios estimated for compounds mainly associated with traffic and LPG emissions were systematically lower by $20 \%$ than those derived directly from measurements, while the values of PMF-derived emission ratios for secondary + long-lived compounds were larger by an average of $80 \%$. As described in Sect. 4.2.2 above, emission ratios for OVOCs were calculated only from the measured data from 04:00 to 07:00 local time, when the direct emissions should dominate the variability of these species. Emission ratios for OVOCs estimated from the traffic + LPG factors from the PMF analysis attempt to include only the directly emitted fraction of the OVOCs. Thus, both methods used here for calculating OVOC emission ratios attempt to correct measurements for secondary production. Uncertainty in the emission ratios calculated from PMF results is dominated by the uncertainties in the PMF results, particularly strongly for OVOCs.

\subsubsection{Limitations of the PMF analysis as applied to VOC measurements}

Some limitations of the application of PMF to VOC mixing ratios became apparent over the course of this work. First, the bilinear unmixing model makes the assumption that the species identified together in one factor occur in constant relative proportions over the entire measurement period. However, individual VOCs and OVOCs have photochemical lifetimes $\left(k_{\mathrm{OH}}\right)$ that span several orders of magnitude, and so VOCs emitted from a single source are removed in the atmosphere at very different rates and thus the ratios of their concentrations will change continuously. This helps explain

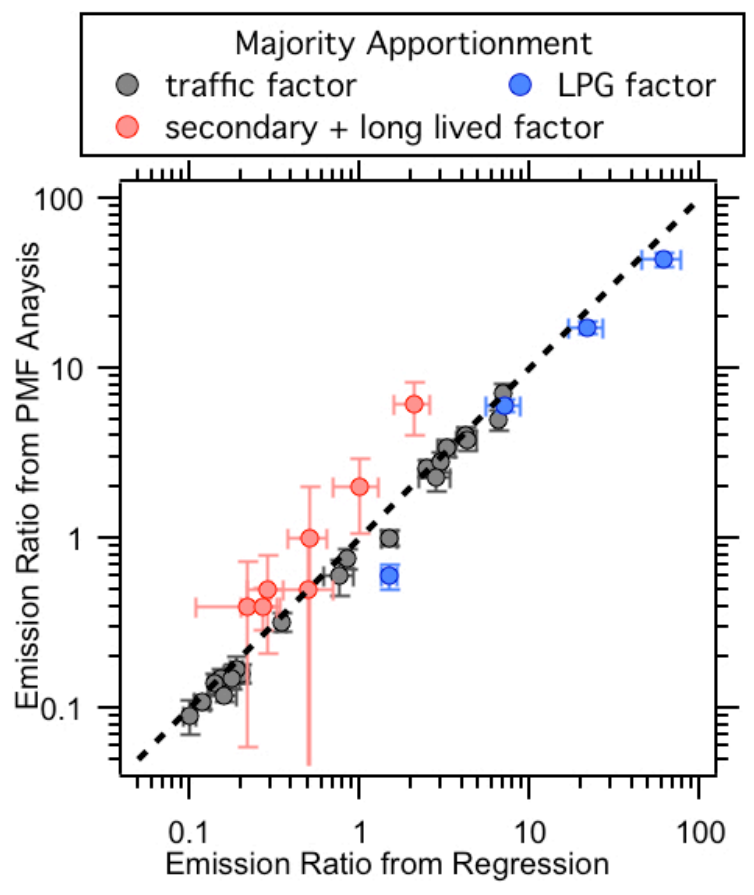

Fig. 13. Comparison of PMF emission ratio estimates obtained by linear regression for all measured compounds. Each point represents one compound while colors represent the dominant PMF apportionment for the respective measurement.

the way individual VOCs are apportioned between the factors. For example, the traffic factor closely matches the diurnal variability of the shortest-lived compounds that have low mixing ratios, while primary hydrocarbons with long lifetimes are partially explained by the secondary + long-lived species factor in proportion to their photochemical lifetimes (Fig. 14), because they are still present in highly processed air. As another example, strict interpretation of the PMF factors (Fig. 9) as sources would suggest that a small portion of toluene and methanol can be attributed to LPG leakage and that benzene and propane are partially attributed to secondary formation, even when this contradicts our knowledge of the sources of these compounds. Thus, the PMF factors identified for this dataset reflect the convolution of VOC sources and VOC lifetimes, and interpretation of the factor profiles strictly in terms of different sources is inappropriate.

Second, for this dataset, the fraction of the variation for some important LPG and OVOC species (e.g., n-butane and acetone) explained by each factor was strongly dependent on the FPEAK parameter (Fig. 10). Known characteristics of sources and lifetimes for these VOCs did not help to significantly narrow the range of FPEAKs of plausible or physically reasonable solutions. For some species, therefore, it is difficult to quantify the fraction emitted by particular sources with much certainty. 


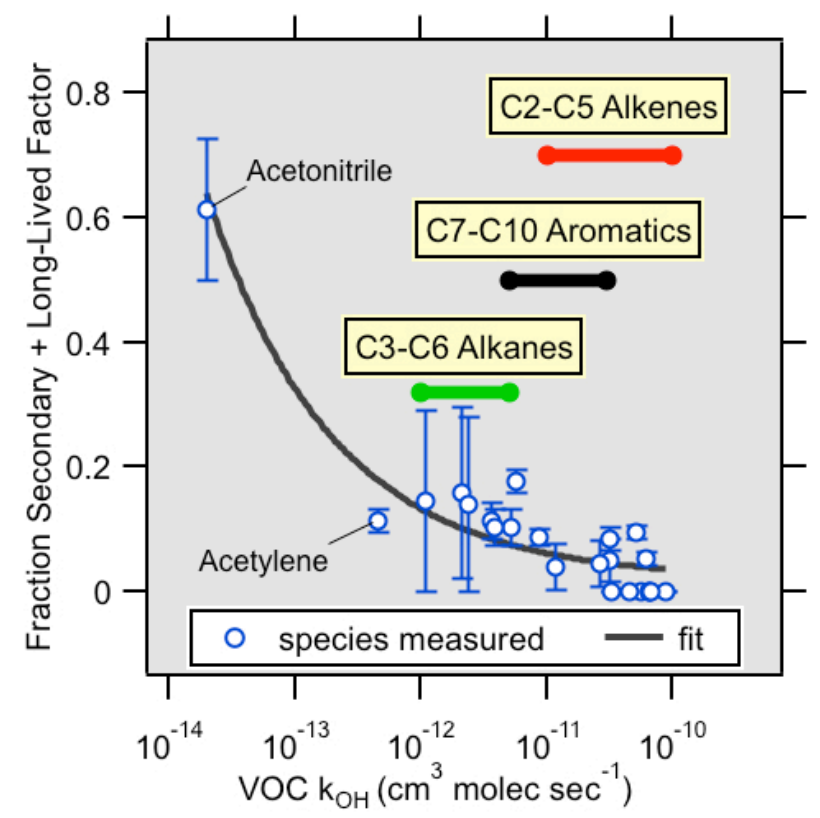

Fig. 14. PMF apportionment of measured compounds to the secondary + long-lived factor plotted versus photochemical lifetime $\left(k_{\mathrm{OH}}\right)$ (Atkinson and Arey, 2003). Longer lifetimes are associated with higher secondary + long-lived source apportionment. Colored bars represent the range of lifetimes by compound class for alkanes (green), aromatics (black) and alkenes (red). Error bars represent variability in apportionment due to PMF FPEAK parameter from -3 to 3 .

\section{Conclusions}

Two ground-based NOAA instruments were deployed during the MILAGRO campaign that provided quantitative analysis of 30 VOCs. Comparison of measurements from these two instruments with canister samples and two mobile PTR-MS instruments was performed and the measurements agreed within uncertainty estimates for most compounds.

PIT-MS provided on-line quantification of 12 VOCs and was used to monitor an additional $150+$ product ion masses. The full mass scan of the PIT-MS instrument proved useful in identifying signal that might have been missed by a quadrupole PTR-MS and the use of the GC pre-separation method provided valuable identification and validation of PIT-MS measurements during the study. Many species quantified by the PIT-MS showed little evidence of interference from other compounds. About $85 \%$ of the total PIT-MS signal arose from identified compounds. Signals at 69 and $71 \mathrm{amu}$, commonly associated with biogenic emissions at other locations, appear to be dominated by traffic emissions in the MCMA. Product ion masses 69, 71, 75, 85, and $87 \mathrm{amu}$ accounted for a large fraction of the unidentified signal from PIT-MS.
Values for VOC and OVOC emission ratios with respect to $\mathrm{CO}$ were reported from Mexico City are presented and compared with previously reported values from US cities. Urban VOC emissions in the MCMA are dominated by traffic emissions and LPG usage. Emission ratios to CO for most hydrocarbons are generally about a factor of two larger than in the United States, while emission ratios to $\mathrm{CO}_{2}$ are likely a factor of $(6 \pm 2)$ larger than US values. Urban OVOC emission ratios in Mexico City, calculated by two different methods appear consistent with vehicular sources of these compounds, although measurement uncertainties are large.

Positive Matrix Factorization analysis performed on the combined data from the two NOAA instruments allowed the identification of 3 dominant factors: traffic, LPG usage and secondary production and long-lived species. These factors described much of the variability in VOC mixing ratios, especially for compounds with vehicular and liquid propane gas sources. OVOCs and compounds with long photochemical lifetimes were identified as a single factor in the analysis. PMF solutions with more than 3 factors resulted in splitting of major factors rather than the identification of minor emission sources. The PMF analysis did not identify distinct factors consistent with industrial, biomass burning or biogenic VOC emissions. Factor profiles (grouping of VOC species) are influenced by both sources and photochemical lifetimes of individual VOCs.

PMF results were also used to estimate emission ratios for VOCs and OVOCs. Estimates agreed within uncertainties with the corresponding emission ratios derived directly from measurements for most hydrocarbons typically associated with vehicle usage. PMF-derived emission ratios were about $20 \%$ lower and $80 \%$ higher for light alkanes and OVOCs respectively. We conclude that PMF describes major VOCs well, but strongly caution against the over-interpretation of PMF factors as strictly corresponding to sources of VOCs because the factors may reflect combinations of sources and photochemical lifetimes, and because solutions may not be unique with respect to rotation.

Acknowledgements. This publication was also developed under a STAR Research Assistance Agreement No. FP-9163901-0 awarded by the US Environmental Protection Agency. It has not been formally reviewed by the EPA. The views expressed in this publication or other work are solely those of its authors. The EPA does not endorse any products or commercial services mentioned in this publication. This work was also financially supported by the National Science Foundation under grants ATM-0516610 and ATM-0513035.

Edited by: L. Molina 


\section{References}

Apel, E. C., Calvert, J. G., and Fehsenfeld, F. C.: The Nonmethane Hydrocarbon Intercomparison Experiment (NOMHICE) - Task1 and Task-2, J. Geophys. Res.-Atmos., 99, 16651-16664, 1994.

Apel, E. C., Emmons, L. K., Karl, T., Flocke, F., Hills, A. J., Madronich, S., Lee-Taylor, J., Fried, A., Weibring, P., Walega, J., Richter, D., Tie, X., Mauldin, L., Campos, T., Weinheimer, A., Knapp, D., Sive, B., Kleinman, L., Springston, S., Zaveri, R., Ortega, J., Voss, P., Blake, D., Baker, A., Warneke, C., Welsh-Bon, D., de Gouw, J., Zheng, J., Zhang, R., Rudolph, J., Junkermann, W., and Riemer, D. D.: Chemical evolution of volatile organic compounds in the outflow of the Mexico City Metropolitan area, Atmos. Chem. Phys., 10, 2353-2375, doi:10.5194/acp-10-23532010, 2010.

Atkinson, R. and Arey, J.: Atmospheric degradation of volatile organic compounds, Chem. Rev., 103, 4605-4638, 2003.

Baker, A. K., Beyersdorf, A. J., Doezema, L., Katzenstein, A., Meinardi, S., Simpson, I., Blake, D. R., and Rowland, F. S.: Measurements of nonmethane hydrocarbons in 28 United States cities, Atmos. Environ., 42, 170-182, 2008.

Ban-Weiss, G. A., McLaughlin, J. P., Harley, R. A., Kean, A. J., Grosjean, E., and Grosjean, D.: Carbonyl and Nitrogen Dioxide Emissions From Gasoline-and Diesel-Powered Motor Vehicles, Environ. Sci. Technol., 42, 3944-3950, 2008.

Blake, D. R. and Rowland, F. S.: Urban Leakage of Liquefied Petroleum Gas and Its Impact on Mexico-City Air-Quality, Science, 269, 953-956, 1995.

Brown, S. G., Frankel, A., and Hafner, H. R.: Source apportionment of VOCs in the Los Angeles area using positive matrix factorization, Atmos. Chem. Phys. Discuss., in preparation, 2010.

Brunekreef, B. and Forsberg, B.: Epidemiological evidence of effects of coarse airborne particles on health, Eur. Resp. J., 26, 309-318, 2005.

Buzcu, B. and Fraser, M. P.: Source identification and apportionment of volatile organic compounds in Houston, TX, Atmos. Environ., 40, 2385-2400, 2006.

Colman, J. J., Swanson, A. L., Meinardi, S., Sive, B. C., Blake, D. R., and Rowland, F. S.: Description of the analysis of a wide range of volatile organic compounds in whole air samples collected during PEM-Tropics A and B, Anal. Chem., 73, 37233731, 2001.

de Gouw, J. A. and Warneke, C.: Measurements of volatile organic compounds in the Earth's atmosphere using proton-transferreaction mass spectrometry, Mass Spec. Rev., 26, 223-257, 2007.

de Gouw, J. A., Goldan, P. D., Warneke, C., Kuster, W. C., Roberts, J. M., Marchewka, M., Bertman, S. B., Pszenny, A. A. P., and Keene, W. C.: Validation of proton transfer reaction-mass spectrometry (PTR-MS) measurements of gas-phase organic compounds in the atmosphere during the New England Air Quality Study (NEAQS) in 2002, J. Geophys. Res.-Atmos., 108, 4682, doi:10.1029/2003JD003863, 2003.

de Gouw, J. A., Cooper, O. R., Warneke, C., Hudson, P. K., Fehsenfeld, F. C., Holloway, J. S., Hubler, G., Nicks, D. K., Nowak, J. B., Parrish, D. D., Ryerson, T. B., Atlas, E. L., Donnelly, S. G., Schauffler, S. M., Stroud, V., Johnson, K., Carmichael, G. R., and Streets, D. G.: Chemical composition of air masses transported from Asia to the US West Coast during ITCT 2K2: Fossil fuel combustion versus biomass-burning signatures, J. Geophys.
Res.-Atmos., 109, D23S20, doi:10.1029/2003JD004202, 2004.

de Gouw, J. A., Middlebrook, A. M., Warneke, C., et al.: Budget of organic carbon in a polluted atmosphere: Results from the New England Air Quality Study in 2002, J. Geophys. Res.-Atmos., 110, D16305, doi:10.1029/2004JD005623, 2005.

de Gouw, J. A., Welsh-Bon, D., Warneke, C., Kuster, W. C., Alexander, L., Baker, A. K., Beyersdorf, A. J., Blake, D. R., Canagaratna, M., Celada, A. T., Huey, L. G., Junkermann, W., Onasch, T. B., Salcido, A., Sjostedt, S. J., Sullivan, A. P., Tanner, D. J., Vargas, O., Weber, R. J., Worsnop, D. R., Yu, X. Y., and Zaveri, R.: Emission and chemistry of organic carbon in the gas and aerosol phase at a sub-urban site near Mexico City in March 2006 during the MILAGRO study, Atmos. Chem. Phys., 9, 3425-3442, doi:10.5194/acp-9-3425-2009, 2009.

Diaz, L., Schifter, I., Lopez-Salinas, E., Gamas, E., Rodriguez, R., and Avalos, S.: Optimizing automotive LPG blend for Mexico city, Fuel, 79, 79-88, 2000.

Edgerton, S. A., Bian, X., Doran, J. C., et al.: Particulate air pollution in Mexico City: A collaborative research project, J. Air Waste Manage., 49, 1221-1229, 1999.

Engel-Cox, J. A. and Weber, S. A.: Compilation and assessment of recent positive matrix factorization and UNMIX receptor model studies on fine particulate matter source apportionment for the eastern United States, J. Air Waste Manage., 57, 1307-1316, 2007.

Fast, J. D., de Foy, B., Acevedo Rosas, F., Caetano, E., Carmichael, G., Emmons, L., McKenna, D., Mena, M., Skamarock, W., Tie, X., Coulter, R. L., Barnard, J. C., Wiedinmyer, C., and Madronich, S.: A meteorological overview of the MILAGRO field campaigns, Atmos. Chem. Phys., 7, 2233-2257, doi:10.5194/acp-7-2233-2007, 2007.

Fast, J., Aiken, A. C., Allan, J., Alexander, L., Campos, T., Canagaratna, M. R., Chapman, E., DeCarlo, P. F., de Foy, B., Gaffney, J., de Gouw, J., Doran, J. C., Emmons, L., Hodzic, A., Herndon, S. C., Huey, G., Jayne, J. T., Jimenez, J. L., Kleinman, L., Kuster, W., Marley, N., Russell, L., Ochoa, C., Onasch, T. B., Pekour, M., Song, C., Ulbrich, I. M., Warneke, C., WelshBon, D., Wiedinmyer, C., Worsnop, D. R., Yu, X.-Y., and Zaveri, R.: Evaluating simulated primary anthropogenic and biomass burning organic aerosols during MILAGRO: implications for assessing treatments of secondary organic aerosols, Atmos. Chem. Phys., 9, 6191-6215, doi:10.5194/acp-9-6191-2009, 2009.

Finlayson-Pitts, B. J.: Tropospheric Air Pollution: Ozone, Airborne Toxics, Polycyclic Aromatic Hydrocarbons, and Particles, Science, 276, 1045-1051, 1997.

Fortner, E. C. and Knighton, W. B.: Quantitatively resolving mixtures of isobaric compounds using chemical ionization mass spectrometry by modulating the reactant ion composition, Rapid Commun. Mass Spectrom., 22, 2008.

Fortner, E. C., Zheng, J., Zhang, R., Berk Knighton, W., Volkamer, R. M., Sheehy, P., Molina, L., and Andr, M.: Measurements of Volatile Organic Compounds Using Proton Transfer Reaction - Mass Spectrometry during the MILAGRO 2006 Campaign, Atmos. Chem. Phys., 9, 467-481, doi:10.5194/acp-9-467-2009, 2009.

Gilman, J. B., Burkhart, J. F., Lerner, B. M., Williams, E. J., Kuster, W. C., Goldan, P. D., Murphy, P. C., Warneke, C., Fowler, C., Montzka, S. A., Miller, B. R., Miller, L., Oltmans, S. J., Ryerson, T. B., Cooper, O. R., Stohl, A., and de Gouw, J. A.: 
Ozone variability and halogen oxidation within the Arctic and sub-Arctic springtime boundary layer, Atmos. Chem. Phys., 10, 10223-10236, doi:10.5194/acp-10-10223-2010, 2010.

Goldan, P. D., Parrish, D. D., Kuster, W. C., Trainer, M., McKeen, S. A., Holloway, J., Jobson, B. T., Sueper, D. T., and Fehsenfeld, F. C.: Airborne measurements of isoprene, $\mathrm{CO}$, and anthropogenic hydrocarbons and their implications, J. Geophys. Res.-Atmos., 105, 9091-9105, 2000.

Goldstein, A. H. and Galbally, I. E.: Known and unexplored organic constituents in the Earth's atmosphere, Environ. Sci. Technol., 41, 1514-1521, 2007.

Guenther, A., Hewitt, C. N., Erickson, D., Fall, R., Geron, C., Graedel, T., Harley, P., Klinger, L., Lerdau, M., McKay, W. A., Pierce, T., Scholes, B., Steinbrecher, R., Tallamraju, R., Taylor, J., and Zimmerman, P.: A global model of natural volatile organic compound emissions, J. Geophys. Res.-Atmos., 100, 8873-8892, 1995.

Guenther, A., Karl, T., Harley, P., Wiedinmyer, C., Palmer, P. I., and Geron, C.: Estimates of global terrestrial isoprene emissions using MEGAN (Model of Emissions of Gases and Aerosols from Nature), Atmos. Chem. Phys., 6, 3181-3210, doi:10.5194/acp-63181-2006, 2006.

Hallquist, M., Wenger, J. C., Baltensperger, U., Rudich, Y., Simpson, D., Claeys, M., Dommen, J., Donahue, N. M., George, C., Goldstein, A. H., Hamilton, J. F., Herrmann, H., Hoffmann, T., Iinuma, Y., Jang, M., Jenkin, M. E., Jimenez, J. L., Kiendler-Scharr, A., Maenhaut, W., McFiggans, G., Mentel, Th. F., Monod, A., Prvt, A. S. H., Seinfeld, J. H., Surratt, J. D., Szmigielski, R., and Wildt, J.: The formation, properties and impact of secondary organic aerosol: current and emerging issues, Atmos. Chem. Phys., 9, 5155-5236, doi:10.5194/acp-95155-2009, 2009.

Harley, R. A., Hannigan, M. P., and Cass, G. R.: Respeciation of organic gas emissions and the detection of excess unburned gasoline in the atmosphere, Environ. Sci. Technol., 26, 2395-2408, 1992.

Hayward, S., Hewitt, C. N., Sartin, J. H., and Owen, S. M.: Performance characteristics and applications of a proton transfer reaction-mass spectrometer for measuring volatile organic compounds in ambient air, Environ. Sci. Technol., 36, 1554-1560, 2002.

Heald, C. L., Goldstein, A. H., Allan, J. D., Aiken, A. C., Apel, E., Atlas, E. L., Baker, A. K., Bates, T. S., Beyersdorf, A. J., Blake, D. R., Campos, T., Coe, H., Crounse, J. D., DeCarlo, P. F., de Gouw, J. A., Dunlea, E. J., Flocke, F. M., Fried, A., Goldan, P., Griffin, R. J., Herndon, S. C., Holloway, J. S., Holzinger, R., Jimenez, J. L., Junkermann, W., Kuster, W. C., Lewis, A. C., Meinardi, S., Millet, D. B., Onasch, T., Polidori, A., Quinn, P. K., Riemer, D. D., Roberts, J. M., Salcedo, D., Sive, B., Swanson, A. L., Talbot, R., Warneke, C., Weber, R. J., Weibring, P., Wennberg, P. O., Worsnop, D. R., Wittig, A. E., Zhang, R., Zheng, J., and Zheng, W.: Total observed organic carbon (TOOC) in the atmosphere: a synthesis of North American observations, Atmos. Chem. Phys., 8, 2007-2025, doi:10.5194/acp-82007-2008, 2008.

Herndon, S. C., Onasch, T. B., Wood, E. C., Kroll, J. H., Canagaratna, M. R., Jayne, J. T., Zavala, M. A., Knighton, W. B., Mazzoleni, C., Dubey, M. K., Ulbrich, I. M., Jimenez, J. L., Seila, R., de Gouw, J. A., de Foy, B., Fast, J., Molina, L. T.,
Kolb, C. E., and Worsnop, D. R.: Correlation of secondary organic aerosol with odd oxygen in Mexico City, Geophys. Res. Lett., 35, L15804, doi:10.1029/2008GL034058, 2008.

Jacob, D. J.: Global budget of methanol: Constraints from atmospheric observations, J. Geophys. Res., 110, 17, D08303, doi:10.1029/2004JD005172, 2005.

Karl, T.: Use of proton-transfer-reaction mass spectrometry to characterize volatile organic compound sources at the La Porte super site during the Texas Air Quality Study 2000, J. Geophys. Res., 108(D160), 4508, doi:10.1029/2002JD003333, 2003.

Karl, T., Apel, E., Hodzic, A., Riemer, D. D., Blake, D. R., and Wiedinmyer, C.: Emissions of volatile organic compounds inferred from airborne flux measurements over a megacity, Atmos. Chem. Phys., 9, 271-285, doi:10.5194/acp-9-271-2009, 2009.

Kleinman, L. I., Springston, S. R., Daum, P. H., Lee, Y.-N., Nunnermacker, L. J., Senum, G. I., Wang, J., Weinstein-Lloyd, J., Alexander, M. L., Hubbe, J., Ortega, J., Canagaratna, M. R., and Jayne, J.: The time evolution of aerosol composition over the Mexico City plateau, Atmos. Chem. Phys., 8, 1559-1575, doi:10.5194/acp-8-1559-2008, 2008.

Krupa, S., McGrath, M. T., Andersen, C. P., Booker, F. L., Burkey, K. O., Chappelka, A. H., Chevone, B. I., Pell, E. J., and Zilinskas, B. A.: Ambient ozone and plant health, Plant Dis., 85, 4-12, 2001.

Lanz, V. A., Hueglin, C., Buchmann, B., Hill, M., Locher, R., Staehelin, J., and Reimann, S.: Receptor modeling of $\mathrm{C}_{2}-\mathrm{C}_{7}$ hydrocarbon sources at an urban background site in Zurich, Switzerland: changes between 1993-1994 and 2005-2006, Atmos. Chem. Phys., 8, 2313-2332, doi:10.5194/acp-8-2313-2008, 2008.

Legreid, G., Loov, J. B., Staehelin, J., Hueglin, C., Hill, M., Buchmann, B., Prevot, A. S. H., and Reimann, S.: Oxygenated volatile organic compounds (OVOCs) at an urban background site in Zurich (Europe): Seasonal variation and source allocation, Atmos. Environ., 41, 8409-8423, 2007.

Marr, L. C., Dzepina, K., Jimenez, J. L., Reisen, F., Bethel, H. L., Arey, J., Gaffney, J. S., Marley, N. A., Molina, L. T., and Molina, M. J.: Sources and transformations of particle-bound polycyclic aromatic hydrocarbons in Mexico City, Atmos. Chem. Phys., 6, 1733-1745, doi:10.5194/acp-6-1733-2006, 2006.

Millet, D. B., Goldstein, A. H., Holzinger, R., Williams, B. J., Allan, J. D., Jimenez, J. L., Worsnop, D. R., Roberts, J. M., White, A. B., Hudman, R. C., Bertschi, I. T., and Stohl, A.: Chemical characteristics of North American surface layer outflow: Insights from Chebogue Point, Nova Scotia, J. Geophys. Res.-Atmos., 111(15), D23S53, doi:D23s5310.1029/2006jd007287, 2006.

Millet, D. B., Jacob, D. J., Custer, T. G., de Gouw, J. A., Goldstein, A. H., Karl, T., Singh, H. B., Sive, B. C., Talbot, R. W., Warneke, C., and Williams, J.: New constraints on terrestrial and oceanic sources of atmospheric methanol, Atmos. Chem. Phys., 8, 68876905, doi:10.5194/acp-8-6887-2008, 2008.

Molina, L. T., Kolb, C. E., de Foy, B., Lamb, B. K., Brune, W. H., Jimenez, J. L., Ramos-Villegas, R., Sarmiento, J., ParamoFigueroa, V. H., Cardenas, B., Gutierrez-Avedoy, V., and Molina, M. J.: Air quality in North America's most populous city overview of the MCMA-2003 campaign, Atmos. Chem. Phys., 7, 2447-2473, doi:10.5194/acp-7-2447-2007, 2007.

Molina, L. T., Madronich, S., Gaffney, J. S., Apel, E., de Foy, B., Fast, J., Ferrare, R., Herndon, S., Jimenez, J. L., Lamb, B., 
Osornio-Vargas, A. R., Russell, P., Schauer, J. J., Stevens, P. S., Volkamer, R., and Zavala, M.: An overview of the MILAGRO 2006 Campaign: Mexico City emissions and their transport and transformation, Atmos. Chem. Phys., 10, 8697-8760, doi:10.5194/acp-10-8697-2010, 2010.

Olivier, J. G. J., Van Aardenne, J. A., Dentener, F. J., Ganzeveld, L., and Peters, J. A. H. W.: Recent trends in global greenhouse gas emissions: regional trends and spatial distribution of key sources, in: Non- $\mathrm{CO}_{2}$ Greenhouse Gases (NCGG-4), edited by: van Amstel, A., 325-330, Millpress, Rotterdam, 2005.

Paatero, P.: Least squares formulation of robust non-negative factor analysis, Chemometr. Intell. Lab., 37, 23-35, 1997.

Paatero, P. and Hopke, P. K.: Discarding or downweighting highnoise variables in factor analytic models, Anal. Chim. Acta, 490, 277-289, 2003.

Paatero, P. and Hopke, P. K.: Rotational Tools for Factor Analytic Models, J. Chemometr., 23, 91-100, 2009.

Paatero, P. and Tapper, U.: Positive matrix factorization: A nonnegative factor model with optimal utilization of error estimates of data values, Environmetrics, 5, 111-126, 1994.

Parrish, D. D., Holloway, J. S., and Fehsenfeld, F. C.: Routine, continuous measurement of carbon-monoxide with parts-per-billion precision, Environ. Sci. Technol., 28, 1615-1618, 1994.

Ramanathan, V., Ramana, M. V., Roberts, G., Kim, D., Corrigan, C., Chung, C., and Winker, D.: Warming trends in Asia amplified by brown cloud solar absorption, Nature, 448, 575-578, doi:10.1038/nature06019, 2007.

Reff, A., Eberly, S. I., and Bhave, P. V.: Receptor modeling of ambient particulate matter data using positive matrix factorization: Review of existing methods, J. Air Waste Manage., 57, 146-154, 2007.

Reimann, S. and Lewis, A. C., Anthropogenic VOCs, in: Volatile Organic Compounds in the Atmosphere, edited by: Koppman, R., Blackwell Publishing Ltd., Oxford, UK, 2007.

Rogers, T., Grimsrud, E., Herndon, S. C., Jayne, J. Kolb, C. E., Allwine, E., Westberg, H., Lamb, B. K., Zavala, M., and Molina, L. T.: On-road measurements of volatile organic compounds in the Mexico City metropolitan area using proton transfer reaction mass spectrometry, Int. J. Mass Spectrom., 252, 26-37, 2006.

Shaw, W. J., Pekour, M. S., Coulter, R. L., Martin, T. J., and Walters, J. T.: The daytime mixing layer observed by radiosonde, profiler, and lidar during MILAGRO, Atmos. Chem. Phys. Discuss., 7, 15025-15065, doi:10.5194/acpd-7-15025-2007, 2007.

Slowik, J. G., Vlasenko, A., McGuire, M., Evans, G. J., and Abbatt, J. P. D.: Simultaneous factor analysis of organic particle and gas mass spectra: AMS and PTR-MS measurements at an urban site, Atmos. Chem. Phys., 10, 1969-1988, doi:10.5194/acp-10-19692010, 2010.

Song, Y., Shao, M., Liu, Y., Lu, S. H., Kuster, W., Goldan, P., and Xie, S. D.: Source apportionment of ambient volatile organic compounds in Beijing, Environ. Sci. Technol., 41, 4348-4353, 2007.

Takegawa, N., Kondo, Y., Koike, M., Chen, G., Machida, T., Watai, T., Blake, D. R., Streets, D. G., Woo, J. H., Carmichael, G. R., Kita, K., Miyazaki, Y., Shirai, T., Liley, J. B., and Ogawa, T.: Removal of $\mathrm{NO}_{\mathrm{x}}$ and $\mathrm{NO}_{\mathrm{y}}$ in Asian outflow plumes: Aircraft measurements over the western Pacific in January 2002, J. Geophys. Res.-Atmos., 109(16), D23S04, doi:D23s0410.1029/2004jd004866, 2004.
Ulbrich, I. M., Canagaratna, M. R., Zhang, Q., Worsnop, D. R., and Jimenez, J. L.: Interpretation of organic components from Positive Matrix Factorization of aerosol mass spectrometric data, Atmos. Chem. Phys., 9, 2891-2918, 2009,

http://www.atmos-chem-phys.net/9/2891/2009/.

van Zelm, R., Huijbregts, M. A. J., den Hollander, H. A., van Jaarsveld, H. A., Sauter, F. J., Struijs, J., van Wijnen, H. J., and van de Meent, D.: European characterization factors for human health damage of $\mathrm{PM}_{10}$ and ozone in life cycle impact assessment, Atmos. Environ., 42, 441-453, 2008.

Vay, S. A., Tyler, S. C., Choi, Y., Blake, D. R., Blake, N. J., Sachse, G. W., Diskin, G. S., and Singh, H. B.: Sources and transport of $\Delta^{14} \mathrm{C}$ in $\mathrm{CO}_{2}$ within the Mexico City Basin and vicinity, Atmos. Chem. Phys., 9, 4973-4985, doi:10.5194/acp-9-4973-2009, 2009.

Vega, E., Mugica, V., Carmona, R., and Valencia, E.: Hydrocarbon source apportionment in Mexico City using the chemical mass balance receptor model, Atmos. Environ., 34, 4121-4129, 2000.

Velasco, E., Lamb, B., Westberg, H., Allwine, E., Sosa, G., ArriagaColina, J. L., Jobson, B. T., Alexander, M. L., Prazeller, P., Knighton, W. B., Rogers, T. M., Grutter, M., Herndon, S. C., Kolb, C. E., Zavala, M., de Foy, B., Volkamer, R., Molina, L. T., and Molina, M. J.: Distribution, magnitudes, reactivities, ratios and diurnal patterns of volatile organic compounds in the Valley of Mexico during the MCMA 2002 \& 2003 field campaigns, Atmos. Chem. Phys., 7, 329-353, doi:10.5194/acp-7-329-2007, 2007.

Veres, P., Roberts, J. M., Warneke, C., Welsh-Bon, D., Zahniser, M., Herndon, S., Fall, R., and de Gouw, J.: Development of negativeion proton-transfer chemical-ionization mass spectrometry (NIPT-CIMS) for the measurement of gas-phase organic acids in the atmosphere, Int. J. Mass Spectrom., 274, 48-55, 2008.

Volkamer, R., Jimenez, J. L., San Martini, F., Dzepina, K., Zhang, Q., Salcedo, D., Molina, L. T., Worsnop, D. R., and Molina, M. J.: Secondary organic aerosol formation from anthropogenic air pollution: Rapid and higher than expected, Geophys. Res. Lett., 33(4), L17811, doi:10.1029/2006GL026899, 2006.

Warneke, C., de Gouw, J. A., Kuster, W. C., Goldan, P. D., and Fall, R.: Validation of atmospheric VOC measurements by proton-transfer-reaction mass spectrometry using a gaschromatographic preseparation method, Environ. Sci. Technol., 37, 2494-2501, 2003.

Warneke, C., de Gouw, J. A., Lovejoy, E. R., Murphy, P. C., Kuster, W. C., and Fall, R.: Development of proton-transfer ion trap-mass spectrometry: On-line detection and identification of volatile organic compounds in air, J. Am. Soc. Mass Spectrom., 16, 1316-1324, 2005a.

Warneke, C., Kato, S., De Gouw, J. A., Goldan, P. D., Kuster, W. C., Shao, M., Lovejoy, E. R., Fall, R., and Fehsenfeld, F. C.: Online volatile organic compound measurements using a newly developed proton-transfer ion-trap mass spectrometry instrument during New England Air Quality Study - Intercontinental Transport and Chemical Transformation 2004: Performance, intercomparison, and compound identification, Environ. Sci. Technol., 39, 5390-5397, 2005b.

Warneke, C., Mckeen, S. A., de Gouw, J. A., Goldan, P. D., Kuster, W. C., Holloway, J. S., Williams, E. J., Lerner, B. M., Parrish, D. D., Trainer, M., Fehsenfeld, F. C., Kato, S., Atlas, E. L., Baker, A. K., and Blake, D. R.: Determination of ur- 
D. M. Bon et al.: Measurements of volatile organic compounds at a suburban ground site

ban volatile organic compound emission ratios and comparison with an emissions database, J. Geophys. Res., 112(13), D10S47 doi:10.1029/2006JD007930, 2007.

Williams, J. and Koppmann, R., Volatile Organic Compounds in the Atmosphere: An Overview, in: Volatile Organic Compounds in the Atmosphere, edited by: Koppman, R., 1-32, Blackwell Publishing Ltd., Oxford, UK, 2007.

World Health Organization, Factsheet on air quality and health, 2008 update, available at:http://www.who.int/mediacentre/ factsheets/fs313/en/index.html, 2008.
Yokelson, R. J., Christian, T. J., Karl, T. G., and Guenther, A.: The tropical forest and fire emissions experiment: laboratory fire measurements and synthesis of campaign data, Atmos. Chem. Phys., 8, 3509-3527, doi:10.5194/acp-8-3509-2008, 2008.

Zhao, W. X., Hopke, P. K., and Karl, T.: Source identification of volatile organic compounds in Houston, Texas, Environ. Sci. Technol., 38, 1338-1347, 2004. 